University of San Diego

Digital USD

University of San Diego Public Law and Legal

Theory Research Paper Series

Law Faculty Scholarship

September 2004

\title{
Strategic Judicial Lawmaking: An Empirical Investigation of Ideology and Publication on the U.S. Court of Appeals for the Ninth Circuit
}

David S. Law

University of San Diego School of Law, hrenchir@SanDiego.edu

Follow this and additional works at: https://digital.sandiego.edu/lwps_public

Part of the Constitutional Law Commons, Courts Commons, Judges Commons, Jurisdiction Commons, Jurisprudence Commons, and the Legal Profession Commons

\section{Digital USD Citation}

Law, David S., "Strategic Judicial Lawmaking: An Empirical Investigation of Ideology and Publication on the U.S. Court of Appeals for the Ninth Circuit" (2004). University of San Diego Public Law and Legal Theory Research Paper Series. 22.

https://digital.sandiego.edu/lwps_public/art22

This Article is brought to you for free and open access by the Law Faculty Scholarship at Digital USD. It has been accepted for inclusion in University of San Diego Public Law and Legal Theory Research Paper Series by an authorized administrator of Digital USD. For more information, please contact digital@sandiego.edu. 
Law:

\title{
STRATEGIC JUDICIAL LAWMAKING: IDEOLOGY, PUBLICATION, AND ASYLUM LAW IN THE NINTH GIRGUIT
}

\author{
David S. Law*
}

\section{INTRODUCTION}

The unpublished opinions of the federal courts of appeals have a paradoxical quality: namely, the bulk of them are published. The thirteen circuit courts decide not to publish 80 percent of their decisions, a proportion that continues to rise as caseloads increase; ${ }^{1}$ for federal district courts, the proportion exceeds 90 percent. $^{2}$ Yet these "unpublished" opinions are matters of public record and are available for most circuits both electronically and in print, whether from third-party publishers or the courts themselves. "What distinguishes "published"

* Assistant Professor of Law, University of San Diego School of Law; Assistant Adjunct Professor of Political Science, University of California, San Diego. This material is based upon work supported under a National Science Foundation Graduate Research Fellowship. Any opinions, findings, conclusions, or recommendations expressed in this publication are those of the author and do not necessarily reflect the views of the National Science Foundation. Stephen Barnett, David Brady, Gerhard Casper, John Ferejohn, Tom Grey, Paul Gribble, Russell Hardin, and Stephen Wasby provided an abundance of valuable suggestions and criticisms. I am indebted above all to Simon Jackman, without whose methodological sophistication and unfailing assistance the central empirical problems posed in this Article would have remained utterly intractable.

1. See David Greenwald \& Frederick A.O. Schwarz, The Censorial fudiciary, 35 U.C. DAvIS L. REv. 1133, 1135, 1146-47 (2002); Memorandum from Judge Samuel A. Alito, Jr., Chair, Advisory Committee on Appellate Rules, to Judge Anthony J. Scirica, Chair, Standing Committee on Rules of Practice and Procedure, Report of Advisory Committee on Appellate Rules (May 22, 2003) (citing ADMINISTRATIVE OFFICE OF the United States Courts, Judicial Business of the United States Courts 2001 tbl. S-3 (2001)), available at http://www.uscourts.gov/rules/app0803.pdf.

2. See Donald R. Songer, Nonpublication in the United States District Courts: Official Criteria Versus Inferences from Appellate Review, 50 J. POL. 206, 206 (1988).

3. See, e.g., Brian P. Brooks, Publishing Unpublished Opinions, 5 GREen BAG 259, 259-63 (2002) (discussing West's Federal Appendix reporter); Greenwald \& Schwarz, supra note 1, at 1138; Richard S. Arnold, Unpublished Opinions: A Comment, 1 J. APP. PraC. \& Process 219, 219-20 (1999). The Fifth and Eleventh Circuits do not make their unpublished decisions available either for electronic distribution (on Westlaw or LexisNexis) or for inclusion in the Federal Appendix, a printed and bound case reporter dedicated to unpublished opinions and offered by West Publishing. See Stephen R. Barnett, From Anastasoff to Hart to West's Federal Appendix: The Ground Shifts Under No-Citation Rules, 4 J. APP. PRAC. \& PROCESs 1, 3-4, 4 n.12 (2002). Nevertheless, practitioners and repeat litigants in those circuits are known to circulate and compile such opinions among themselves. See id. at 6 n.28 (describing the "networks" and "minicollections" evolved by private practitioners, law firms, and government lawyers in the Fifth Circuit); K.K. DuVivier, Are Some Words Better Left Unpublished?: Precedent and the Role of Unpublished Decisions, 3 J. APP. PRAC. \& PROCESS 397, 410 (2001) (noting the access that governmental litigants enjoy to cases previously argued by their respective institutions). The E-Government Act of 2002 will soon compel all circuits to make all of their decisions available on their websites. See E-Government Act of 2002, Pub. L. No. 107-347, § 205(a), 116 Stat. 2899, 2913-14 (2002). 
from "unpublished" opinions is no longer their availability in print, but their precedential effect. The majority of circuits have adopted rules that discourage or prohibit the citation of unpublished opinions. ${ }^{4}$ The late Richard Arnold, who served with distinction on the Eighth Circuit, described the operation of no-citation rules bluntly:

If we mark an opinion as unpublished, it is not precedent. We are free to disregard it without even saying so. Even more striking, if we decided a case directly on point yesterday, lawyers may not even remind us of this fact. The bar is gagged. We are perfectly free to depart from past opinions if they are unpublished, and whether to publish them is entirely our own choice. ${ }^{5}$

The result, as he put it, has been the creation of a "vast underground body of law ... disavowed by the very judges who are producing it."

The practice of issuing opinions that cannot be cited - of authoring what is, in a sense, "secret law"7 - is intensely controversial. Its constitutionality has been the subject of considerable discussion, thanks in part to the short-lived holding of an Eighth Circuit panel that federal courts lack the power under Article III to choose which of their decisions are to have precedential effect. ${ }^{8}$ The fact that publication

4. Five of the thirteen circuits have in place rules that prohibit citation of unpublished opinions except under highly specific circumstances; another four discourage such citation and stipulate that unpublished opinions do not constitute binding authority. The D.C. Gircuit recently abandoned its nocitation rule and now permits citation of all cases decided after January 1, 2002. See Greenwald \& Schwarz, supra note 1, at 1139 n.8; Barnett, supra note 3, at 3-4, 3 n.11 (discussing D.C. CIR. R. 28(c)(12)(B), 36(c)(2)).

5. Arnold, supra note 3, at 221.

6. Id. at 225 .

7. Barnett, supra note 3 , at 3 n.11 (quoting an unnamed D.C. Circuit judge's criticism of unpublished decisions as "secret law"); see also, e.g., Patricia M. Wald, The Rhetoric of Results and the Results of Rhetoric: fudicial Writings, 62 U. CHI. L. REv. 1371, 1374 (1995) ("Lawyers and commentators regularly raise the specter of "secret justice," "unequal justice," and "sloppy justice" stemming from the growing popularity of unpublished dispositions, particularly in appellate courts[.]").

8. See Anastasoff v. United States, 223 F.3d 898, 903-05 (8th Gir. 2000) (R. Arnold, J.). An en banc panel—-led byJudge Arnold, who had authored the original panel opinion—vacated the decision as moot but took pains to leave open the constitutional question that had preoccupied the panel. See Anastasoff v. United States, 235 F.3d 1054, 1055-56 (8th Gir. 2000) (en banc) (R. Arnold, J.); Greenwald \& Schwartz, supra note 1, at 1160 n.108 (discussing the "strange, short life" of the original panel's decision in Anastasoff). Commentators have also advanced the argument that prohibitions against citation of unpublished opinions violate the First Amendment by restricting speech about particular government acts and impinging upon the right to petition for redress of grievances. See Greenwald \& Schwarz, supra note 1, at 1162-66. Such arguments have met with considerable skepticism: the Ninth Circuit, for example, has not merely repudiated Anastasoff but stands prepared to sanction litigants who cite unpublished opinions. See Hart v. Massanari, 266 F.3d 1155, 1159-80 (9th Cir. 2001). For discussion of the reaction to Anastasoff, see Deborah Jones Merritt \& James J. Brudney, Stalking Secret Law: What Predicts Publication in the United States Courts of Appeals, 54 VAND. L. REv. 71, 118 \& n.43 (2001). For examples of academic commentary on the case and on limited publication practices more generally, see Symposium, Anastasoff, Unpublished Opimions, and "No Citation" Rules, 3 J. APP. PRAC. \& PROCESS 169 (2001); the symposium held on March 18, 2005, at the Washington \& Lee University School of Law, entitled "Have We Ceased to Be a Common Law 
practices vary across circuits has also attracted criticism: the existence of no-citation rules in some circuits, but not others, means that practitioners face sanctions if they cite unpublished cases in certain circuits, yet risk negligence if they fail to do so in others. ${ }^{9}$ For these and other reasons, the Judicial Conference of the United States is actively contemplating a nationwide repeal of no-citation rules. ${ }^{10}$

Relatively little attention, however, has been paid to the possibility that judges make strategic use of publication rules to shape the development of case law in an ideological direction. As Judge Patricia Wald of the D.C. Circuit has observed, limited publication rules have created a "double-track system" that invites "deviousness and abuse" by enabling judges to publish decisions selectively, in furtherance of ideological or policy goals. ${ }^{11}$ Even if judges find themselves constrained by the facts

Country?: A Conversation on Unpublished, Depublished, Withdrawn, and Per Curiam Opinions"; and also Barnett, cited above in note 3 .

State no-citation rules have attracted their share of opposition as well. See, e.g., Adam Liptak, Federal Appeals Court Decisions May Go Public, N.Y. TIMES, Dec. 25, 2002, at A1, as corrected, Jan. 10, 2003, at A21 (describing the Texas Supreme court's recent repeal of no-citation rules); Philip L. DuBois, The Negative Side of fudicial Decision Making: Depublication as a Tool of fudicial Power and Administration on State Courts of Last Resort, 33 VIILL. L. REV. 469, 476-79 (1988) (reviewing criticisms leveled by judges and others against California's limited publication and depublication rules); Penelope Pether, Inequitable Injunctions: The Scandal of Private fudging in the U.S. Courts, 56 STAN. L. REV. 1435, 1479-83, 1498-1504 (2004) (describing, and condemning, depublication practices in California); The Committee for the Rule of Law, at http://www.nonpublication.com (last visited Feb. 20, 2004) (arguing for repeal of both state and federal limited publication rules).

9. See Alito, supra note 1, at 31-32.

10. The Judicial Conference has proposed the adoption of a uniform national rule that would prevent individual circuits from adopting or enforcing no-citation rules. See Alito, supra note 1, at 27-36 (recommending adoption of proposed Federal Rule of Appellate Procedure 32.1). But no-citation rules have judicial supporters who are adamantly opposed to the change. See, e.g., Alex Kozinski \& Stephen Reinhardt, Please Don't Cite This! Why We Don't Allow Citation to Unpublished Dispositions, CAL. LAW. June 20, 2000, at 43; Liptak, supra note 8, at A21 (quoting Judge Kozinski, and reporting that the concerns of several judges on the Ninth Circuit have led the Solicitor General to refrain from supporting a repeal of the no-citation rules); Letter from Stephen Reinhardt, Circuit Judge, 9th Cir., to former law clerks, Nov. 24, 2003 (on file with the author) (urging former law clerks to voice their opposition). Unsurprisingly, the public comment period on proposed Rule 32.1 attracted a considerable volume of comments, including an overwhelmingly negative response from Ninth Circuit judges. See Secret Justice, at http://www. secretjustice.org/new_proposed_frap_32_1.htm\#complete_list_public_comments (last visited Feb. 20, 2004) (setting forth all public comments on the rule). In June of 2004, the Conference's Committee on Rules of Practice and Procedure postponed action on Rule 32.1 pending the outcome of further study by the Federal Judicial Center. See Stephen L. Wasby, Unpublished Court of Appeals Decisions: A Hard Look at the Process, 13 S. GAL. INTERDISC. L.J. _ (forthcoming 2005). Even if it is eventually approved by all relevant committees, the Conference itself, the Supreme Court, and Congress, the proposed change would not take effect for over a year. See Administrative Office of the U.S. Courts, Pending Rules Amendments Awaiting Final Action, at http://www.uscourts.gov/rules/newrules6.html (last visited Feb. 20, 2004). See generally Leonidas Ralph Mecham, Administrative Office of the U.S. Courts, The Rulemaking Process: A Summary for Bench and Bar, at http://www.uscourts.gov/rules/proceduresum.htm (last modified Sept. 30, 2003) (setting forth the timeline for adoption of new federal court rules).

11. Wald, supra note 7, at 1374 . 
and the law to reach outcomes that conflict with their policy preferences, the fact that they choose which of their opinions will be binding in future cases offers them a further opportunity to advance their preferences by engaging in what amounts to selective lawmaking: they may attempt to steer the evolution of the law in a particular ideological direction by publishing opinions they like, while burying in unpublished form those they do not. ${ }^{12}$ Conversely, judges may exploit the unpublished format to reach ideologically driven results that would attract criticism or even reversal if published: decisions that can never be cited are unlikely to arouse the attention of busy colleagues and receive practically no en banc review. ${ }^{13}$

This Article tests empirically the hypothesis that the decision to publish is influenced by judicial ideology by means of a statistical analysis of all asylum cases decided by the United States Court of Appeals for the Ninth Circuit over the course of a decade. Contrary to previous studies, it finds that there exists, for some judges, a significant relationship between how the judge votes on the merits of the case, and whether the case is published: publication increases the likelihood that certain judges vote in favor of asylum. The results suggest that voting and publication are, for some judges, strategically intertwined: for example, judges may be prepared to acquiesce in decisions that run contrary to their own preferences, and to vote with the majority, as long as the decision remains unpublished, but can be driven to dissent if the majority insists upon publication. In the course of reaching these conclusions, this Article also estimates in numerical terms and compares the ideological attitudes of individual Ninth Circuit judges toward asylum cases.

Part II reviews the existing literature on selective publication practices, with particular emphasis upon empirical findings. Part III introduces the data and explains why asylum cases in the Ninth Circuit were selected for analysis. Part IV describes the publication rules and practices of the Ninth Circuit. Part V sets forth the hypotheses to be explored. Part VI presents the empirical findings, together with some

12. See Peter L. Strauss, Courts or Tribunals? Federal Courts and the Common Law, 53 ALA. L. REv. 891, 896-97 (2002) (observing that "the realities of opinion-writing and publication" "enable[ judges to have agendas").

13. See, e.g., Pierre H. Bergeron, En Banc Practice in the Sixth Circuit: An Empirical Study, 1990-2000, 68 Tenn. L. Rev. 771, 794-96 (2001); Patricia M. Wald, Changing Course: The Use of Precedent in the District of Columbia Circuit, 34 Clev. ST. L. REv. 477, 483-86 (1986) (reporting from experience that most judges "must feel deeply that circuit jurisprudence is significantly threatened to call for an en banc"); Kozinski \& Reinhardt, supra note 10, at 44 (reporting from experience that Ninth Gircuit judges "seldom review the [unpublished decisions] of other panels or take them en banc"); see also Tracey E. George, The Dynamics and Determinants of En Banc Reviewe, 74 WASH. L. REV. 213, 214 (1999) (noting that circuit courts resolve fewer than $1 \%$ of cases en banc). 
discussion of methodological obstacles and solutions. Finally, this Article concludes by calling into question the validity of existing empirical research on the courts of appeals, given the frequent tendency of such work to omit unpublished decisions from analysis.

\section{The Existing Literature on Selective Publication}

The use of unpublished opinions is justified in large part as a matter of practical necessity. Many run no longer than one or two sentences in length: in some circuits, the median length of an unpublished opinion is fewer than fifty words. ${ }^{14}$ Precisely because they are shorter and require less authorial effort than published opinions, their use has been defended by judges as a necessary adaptation to momentous increases in the federal appellate caseload that have far outpaced growth in the number of judges. ${ }^{15}$ These same considerations of judicial economy are also used to justify restrictions on the citation of unpublished opinions: to allow their citation, it is argued, would defeat their very purpose by forcing judges to give them the same attention that published opinions receive. ${ }^{16}$

Evidence suggests that circuit judges have indeed made use of unpublished decisions to manage increasing caseloads, although circuits with lower publication rates do not necessarily decide more cases. Greenwald and Schwarz report that while the number of published opinions per judge remained roughly unchanged between 1960 and 1995, the number of cases decided per judge more than quadrupled in the same period. ${ }^{17}$ Reynolds and Richman found that unpublished opinions are indeed shorter and take less time to complete than their published counterparts, but failed to find a significant correlation

14. See William L. Reynolds \& William M. Richman, An Evaluation of Limited Publication in the United States Courts of Appeals: The Price of Reform, 48 U. CHI. L. REV. 573, 600 tbl.9 (1981).

15. See, e.g., Kozinski \& Reinhardt, supra note 10, at 44 (Ninth Circuit judges); Richard A. POSNER, THE FEDERAl Gourts: Challenge AND REForm 168-69 (1996) (former Chief Judge of the Seventh Circuit); Wald, supra note 7, at 1373-74 (former ChiefJudge of the D.C. Circuit); Bruce M. Selya, Publish and Perish: The Fate of the Federal Appeals fudge in the Information Age, 55 OHIO ST. L.J. 405, 405-10 (1994) (First Circuit judge). The limited publication rules of the Second Circuit contain the explicit justification that " $[\mathrm{t}]$ he demands of an expanding case load require the court to be ever conscious of the need to utilize judicial time effectively." 2D CIR. R. $§ 0.23$.

16. See, e.g., Kozinski \& Reinhardt, supra note 10, at 44; The Honorable Boyce F. Martin, Jr., In Defense of Unpublished Opinions, 60 OHIO ST. L.J. 177, 190-91 (1999); Letter from Diarmuid F. O'Scannlain, Circuit Judge, U.S. Court of Appeals for the Ninth Circuit, to Peter G. McCabe, Secretary, Committee on Rules of Practice and Procedure, Administrative Office of the United States Courts, RE: Proposed Amendments to the Federal Rules of Appellate Procedure 1-3 (Dec. 23, 2003), available at http://www.secretjustice.org/pdf_files/Comments/03-AP-285.pdf (last visited May 12, 2004).

17. See Greenwald \& Schwarz, supra note 1, at 1146-47. 
between a circuit's publication rate and the productivity of its judges, measured in terms of dispositions per judge. ${ }^{18}$

Since its inception in the 1970 s, limited publication has also been justified on the grounds that many cases lack precedential value, and that the addition of large numbers of redundant and inconsequential cases to the published corpus only detracts from the clarity and navigability of the law. ${ }^{19}$ Indeed, the limited publication practices now in place were initially adopted at the urging of the Judicial Conference for the express purpose of curtailing the proliferation of judicial opinions. ${ }^{20}$ The rules of the Fifth Circuit state, for example, that "the publication of opinions that merely decide particular cases on the basis of well-settled principles of law imposes needless expense on the public and burdens on the legal profession."21 This justification presupposes, of course, that there exists a clear distinction between opinions that deserve publication and those that do not, and that judges can and do make that distinction consistently and faithfully. The account given by Boyce Martin, until recently Chief Judge of the Sixth Circuit, exemplifies this view:

The publication decision is, quite simply, almost invariably an easy call to make. Cases either clearly merit publication, or they clearly do not. Therefore, we as judges seldom dicker over the publication issue and seldom make mistakes in dividing up the cases between published and unpublished.... [T] he publication decision is seldom a potential pratfall for a federal appellate judge. ${ }^{22}$

Other judges have taken a less benign view of how publication decisions are reached. Judge Richard Posner, among others, has observed that publication criteria provide judges with little or no guidance, and that judges often cannot tell whether a decision merits publication. ${ }^{23}$ Judge Wald has characterized the official criteria governing

18. See Reynolds \& Richman, supra note 14, at 593-98.

19. See, e.g., Martin, supra note 16 , at 193 ("One does not need to pile on the excessive verbiage of string cites to random, minor cases."); The Honorable Philip Nichols, Jr., Selective Publication of Opinions: One fudge's View, 35 AM. U. L. REV. 909, 912-13, 919-20, 927 (1986).

20. See Michael Hannon, A Closer Look at Unpublished Opinions in the United States Courts of Appeals, $3 \mathrm{~J}$. APP. PRAC. \& PROCESS 199, 207-08 (2001).

21. 5TH CIR. R. 47.5.1.

22. Martin, supra note 16, at 192; see also, e.g., Nichols, supra note 19, at 914 ("[H]ard as it may be for academia to believe, the nonprecedent is really not a precedent, and the rule works as intended.").

23. See POSNER, supra note 15, at 165 ("The criteria for when to publish an opinion are, as in the nature of the problem they must be, imprecise and nondirective; they amount to little more than saying that an opinion should not be published unless it is likely to have value as a precedent. Judges often will not know whether an opinion is likely to have such value."); see also, e.g., Donald R. Songer, Criteria for Publication of Opinions in the U.S. Courts of Appeals: Formal Rules Versus Empirical Reality, 73 JUDICATURE 307, 309 (1990) (observing that the publication criteria of the various circuits "are broad, vague, and give little detailed direction"). 
publication as "infinitely maneuverable," 24 a problem compounded by the fact that "the judges themselves are the only monitors of how faithfully those criteria are applied." ${ }^{, 25}$ In her experience, not only do judges vary in their individual propensity to publish cases, but goaloriented strategic behavior is a very real phenomenon:

I have seen judges purposely compromise on an unpublished decision incorporating an agreed-upon result in order to avoid a timeconsuming public debate about what law controls. I have even seen wily would-be dissenters go along with a result they do not like so long as it is not elevated to a precedent. ${ }^{26}$

Judge Arnold echoed this sentiment:

[I]f, after hearing argument, a judge in conference thinks that a certain decision should be reached, but also believes that the decision is hard to justify under the law, he or she can achieve the result, assuming agreement by the other members of the panel, by deciding the case in an unpublished opinion and sweeping the difficulties under the rug. Again, I'm not saying that this has ever occurred in any particular case, but a system that encourages this sort of behavior, or is at least open to it, has to be subject to question in any world in which judges are human beings. ${ }^{27}$

The empirical literature on publication is sparse. Publication rates vary significantly by judge,${ }^{28}$ circuit, and area of law. ${ }^{29}$ These variations may be attributable to the procedural rules and practices of each circuit, the number and type of cases each court hears, the inclinations of the judges themselves, or some combination thereof. With respect to the written rules governing publication, some circuits provide that decisions are to be published by default; others explicitly disfavor publication. ${ }^{30}$

24. Wald, supra note 7 , at 1374 .

25. Wald, supra note 13, at 501-02.

26. Wald, supra note 7, at 1374 .

27. Arnold, supra note 3 , at 223.

28. See Songer, supra note 23, at 312-13, 313 tbl.4 (noting significantly different rates of participation in published decisions among judges of the Fourth, Eleventh, and D.C. Circuits).

29. See, e.g., Reynolds \& Richman, supra note 14, at 586 tbl.1, 587 tbl.2, 622 tbl.14; Donald R. Songer et al., Nonpublication in the Eleventh Circuit: An Empirical Analysis, 16 FLA. ST. U. L. REV. 963, 981 \& tbls.5, 6, 982 \& tbl.7 (1989) (documenting variations within the Eleventh Circuit in the rates at which appeals in different areas of law are published); Robert A. Mead, "Unpublished" Opimions as the Bulk of the Iceberg: Publication Patterns in the Eighth and Tenth Circuits of the United States Courts of Appeals, 93 LAW LiBR. J. 589, 603 tbl.1, 605 tbl.2, 606 tbl.3 (2001) (documenting variations within the Eighth and Tenth Circuits in the rates at which appeals in different areas of law are published); Hannon, supra note 20, at 209-20 (summarizing publication disparities by circuit and area of law).

30. Compare, e.g., 1ST CIR. R. 36. ("In general, the court thinks it desirable that opinions be published and thus be available for citation."), with, e.g., 7TH CIR. R. 53(a) ("It is the policy of the circuit to reduce the proliferation of published opinions."). 
Some state merely that judges should publish decisions that "add to the body of law"31 or have "general public interest";" others have adopted additional criteria that encourage or require the publication of certain categories of decisions. Typical candidates for publication include cases in which the lower court or agency is reversed (particularly if the decision below was published), split decisions involving a concurrence or dissent, decisions that create or resolve disagreement with another circuit, and cases on remand from the Supreme Court.

Commentators have found the differences between the rules of the various circuits inadequate to explain why actual publication rates vary so widely. ${ }^{33}$ Mead has reported wide variations between circuits with similar publication rules, ${ }^{34}$ while separate studies by Reynolds and Richman ${ }^{35}$ and Merritt and Brudney ${ }^{36}$ found no correlation between the specificity of a circuit's publication criteria and its publication rate. Moreover, it cannot be assumed that formal rules always dictate actual judicial practice. For example, some circuits require a majority of the panel to agree upon publication, while others empower a single judge to trigger publication ${ }^{37}$ or simply do not address the matter. Yet judges have observed that it is often the author of the opinion who decides whether to publish ${ }^{38}$ - an understandable courtesy in light of the fact that the author is responsible for the effort of preparing an opinion for publication.

A pair of early studies appeared to offer support for the conventional view that unpublished cases involve the uncontroversial application of settled law. Based upon a content analysis of unpublished opinions rendered in 1978 and 1979, Reynolds and Richman concluded that

\footnotetext{
31. 8TH CIR. R. APP. I.

32. D.C. GIR. R. 36(A).

33. This view may be shared among judges as well. See Nichols, supra note 19, at 922 ("Despite differences in the way different circuits state their plans, I think it probable that a like case would probably be published, or not published, similarly in all circuits.").

34. See Mead, supra note 29, at 601-07.

35. See Reynolds \& Richman, supra note 14 , at 588-90.

36. See Merritt \& Brudney, supra note 8, at 88.

37. The Second, Fifth, and Federal Circuits fall in this category. See 2D CIR. R. § 0.23; 5 TH CIR. R. 47.5.2; Nichols, supra note 19, at 923 (citing United States Court of Appeals for the Federal Circuit, Standard Operating Procedures No. 7, Publication Policy, Opinions and Orders §6). See generally Melissa M. Serfass \& Jessie L. Cranford, Federal and State Court Rules Governing Publication and Citation of Opinions, $3 \mathrm{~J}$. APP. PRAC. \& PROCESS 251, 253 tbl.1 (setting forth the publication rules of all federal circuits).

38. See, e.g., Arnold, supra note 3, at 221 (noting of his own court, the Eighth Circuit, that the decision to publish "is, as a practical matter, always made by the writing judge"); Wald, supra note 7, at 1374 (observing generally that it is "sometimes only the assigned author" who decides whether to publish); Stephen L. Wasby, Unpublished Decisions in the Federal Courts of Appeals: Making the Decision to Publish, 3 J. APP. PRAC. \& PROCESS 325, 333-35 (2001) (describing practice in the Ninth Circuit). But see Martin, supra note 16, at 188 (noting of his court, the Sixth Circuit, that "[i]f one judge strongly believes in publication, the other judges generally acquiesce to his or her wishes").
} 
circuit judges failed to publish "opinions that clearly broke new ground on important issues" less than 1 percent of the time. ${ }^{39}$ In a similar vein, an evaluation by Schuchman and Gelfand of a limited publication rule in force between 1970 and 1972 in the Fifth Circuit concluded that judges did accurately select opinions of limited precedential value for nonpublication, an inference drawn from the fact that decisions published under the limited publication regime were cited more often than decisions published before or after the rule was in effect. ${ }^{40}$ Schuchman and Gelfand failed to address the possibility, however, that higher citation rates per opinion following the introduction of limited publication simply reflected a reduction in the supply of opinions available for citation.

Subsequent studies have increasingly called the conventional view into question. Examples abound of lengthy and dense unpublished opinions on seemingly controversial topics. ${ }^{41}$ A review of unpublished orders issued by the Seventh Circuit over a six-month period in 1975 found that over 15 percent were of substantive significance and met the criteria for publication. ${ }^{42}$ A subsequent study sponsored by the D.C. Circuit concluded that 40 percent of the unpublished opinions issued over a six-month period in 1983 arguably met the court's publication criteria, a proportion that Judge Wald estimates "would be much higher now." 43 The fact that the vast majority of unpublished cases are unanimous conceals the extent to which they may be characterized by ideological disagreement. ${ }^{44}$ Panels dominated by Democratic appointees render a significantly higher proportion of liberal decisions than panels dominated by Republican appointees, regardless of publication status;

39. Reynolds \& Richman, supra note 14 , at 608-09.

40. See Philip Schuchman \& Alan Gelfand, The Use of Local Rule 21 in the Fifth Circuit: Can fudges Select Cases of "No Precedential Vahue"?, 29 EMORY L.J. 195, 195, 209-18 (1980).

41. See, e.g., Brooks, supra note 3, at 260-63; Mead, supra note 29, at 602-03; Pamela Foa, A Snake in the Path of the Law: The Seventh Circuit's Non-Publication Rule, 39 U. PITT. L. REV. 309, 315-40 (1977).

42. See Foa, supra note 41, at 315-40.

43. Wald, supra note 7, at 1374 (citing a study by the advisory committee to the D.C. Circuit).

44. Dissent behavior, by itself, has been found to understate ideological disagreement on circuit court panels. Separate studies by Revesz and by Cross and Tiller have documented the existence of panel composition effects that mask the extent to which judges actually divide along ideological lines: "Democratic judges 'vote as Democrats' only when there are at least two Democrats on the panel, [and] similarly, Republican judges 'vote as Republicans' only when there are at least two Republicans on the panel." Richard L. Revesz, Environmental Regulation, Ideology, and the D.C. Circuit, 83 VA. L. REv. 1717, 1765-66 (1997). Whether it is majority judges who modify their behavior in response to the presence of a majority judge or minority judges who accommodate themselves to majorities, a lone Republican sitting with two Democrats votes more liberally than if paired with one or more fellow Republicans, and vice versa for lone Democrats sitting with two Republicans. See id.; Frank B. Cross \& Emerson H. Tiller, fudicial Partisanship and Obedience to Legal Doctrine: Whistleblowing on the Federal Courts of Appeals, 107 YALE L.J. 2155, 2168-76 (1998). 
moreover, the extent of this disparity for unpublished opinions rivals what has been observed of published decisions. ${ }^{45}$

Failure to publish reversals, in particular, has been identified repeatedly as a form of underpublication. Because disagreement between an appellate court and a lower court or agency tends to signal uncertainty or conflict in the law, reversals are inherently likely to satisfy publication criteria even in circuits in which they are not specifically singled out for publication. The vast majority of unpublished opinions are in fact affirmances, and reversals are more likely to be published than affirmances. ${ }^{46}$ Nevertheless, significant numbers of reversals continue to escape publication. A survey of all circuits in the late 1970s found that one in seven reversals was not published, ${ }^{47}$ and the trend appears to be increasing: Songer's examination of three circuits in the mid1980s found that over half of the reversals in the D.C. Circuit went unpublished, as did nearly half in the Fourth Circuit and over a third in the Eleventh Circuit. ${ }^{48}$

There is also reason to think that selective publication has, in practice, favored certain types of litigants over others. A study of the Eleventh Circuit conducted by Songer, Smith, and Sheehan found that appeals brought by "underdog" litigants such as prisoners, aliens, labor unions, minorities, and employees are less likely to be selected for publication than those brought by governments or corporations. ${ }^{49}$ A follow-up study also found significant differences in the rates at which different circuits publish such underdog appeals. ${ }^{50}$ Particularly high intercircuit publication disparities have been noted in the areas of habeas corpus, criminal sentencing, Social Security, and certain constitutional claims, ${ }^{51}$ while the Fifth Circuit and the Texas Court of Criminal Appeals have been singled out for underpublication of death penalty appeals. ${ }^{52}$

For its part, the government has actively used selective publication rules to its advantage: as a repeat litigant, it has both the incentive to seek publication of favorable opinions and the ability to make use of them. Robel's 1989 survey of federal appellate litigators confirmed that

\footnotetext{
45. See Songer, supra note 23, at 312; Songer et al., supra note 29, at 977-78; Merritt \& Brudney, supra note 8 , at 108-09.

46. See, e.g., Mead, supra note 29, at 601-04,606 (examining the Eighth and Tenth Circuits); Songer, supra note 23, at 311 (reviewing unpublished decisions of the Fourth, Eleventh, and D.C. Circuits); Merritt \& Brudney, supra note 8, at 91-93, 92 tbl.V, 93 tbl.VI (examining labor appeals across all circuits).

47. See Reynolds \& Richman, supra note 14 , at 617 \& tbl.13.

48. See Songer, supra note 23, at 311.

49. See Songer et al., supra note 29 , at 980-81.

50. See Songer, supra note 23, at 313 tbl.5.

51. See Mead, supra note 29, at 601-06 (comparing the Eighth and Tenth Circuits).

52. David R. Dow \& Bridget T. McNeese, Invisible Executions: A Preliminary Analysis of Publication Rates in Death Penaly Cases in Selected furisdictions, 8 Tex. J. Civ. LiBerties \& CIV. RTS. 149, 173 (2003).
} 
the government does in fact request publication of favorable decisions, and that its attorneys make systematic use of unpublished opinions not only in preparing their legal arguments, but also in identifying cases for litigation, settlement, and appeal. ${ }^{53}$ Independently, Judge Nichols of the Federal Circuit has also observed that government attorneys make more extensive use of unpublished cases than do private litigants. ${ }^{54}$ Robel's examination of the Seventh Circuit further revealed that most decisions to redesignate unpublished cases for publication favor the government, especially federal litigants. ${ }^{55}$

To date, very little research has sought to test whether judges seek to shape the development of case law in a particular ideological direction via selective publication. Moreover, the results of such work have been conflicting and inconclusive. In the death penalty context, Dow and McNeese have concluded that capital defendants in Texas face "secretive and buried" judicial hostility in the form of underpublication by both the Fifth Circuit and Texas's Court of Criminal Appeals, ${ }^{56}$ but they do not suggest that strategically minded judicial supporters of the death penalty are developing the case law in a manner that facilitates capital punishment. Indeed, their finding of underpublication implies the opposite.

An examination by Merritt and Brudney of labor law appeals decided in all circuits over a seven-year period addressed the question more directly but found that the likelihood of publication was affected neither by the ideology of the panel nor the outcome of the case: "Panels with more Democrats showed no tendency to publish pro-union results, nor did they show any inclination to suppress cases rejecting union claims. ${ }^{, 57}$ Pro-union decisions were neither more nor less likely to be published than pro-management decisions, once the higher publication rate for reversals was taken into account. ${ }^{58}$ Similarly, no significant relationship

\footnotetext{
53. See Lauren K. Robel, The Myth of the Disposable Opinion: Unpublished Opinions and Government Litigants in the United States Courts of Appeals, 87 MICH. L. REV. 940, 956-59 (1989).

54. See Nichols, supra note 19, at 917.

55. See Robel, supra note 53, at 958.

56. See Dow \& McNeese, supra note 52, at 173.

57. Merritt \& Brudney, supra note 8 , at 98 .

58. To control for the effect of publication criteria that implicitly or explicitly encourage the publication of reversals, Merritt and Brudney ran an initial regression using appellate pro-union outcome as the sole predictor of publication; the resulting coefficient on outcome was significant. The addition to the model of reversal as an additional predictor, however, both rendered outcome an insignificant predictor of publication and increased the overall explanatory power of the model. See id. at 92-93, 92 tbl.V, 93 tbl.VI.

In the context of asylum, on which this Article focuses, a similar control for reversal would be neither possible nor meaningful because reversal and outcome are perfectly collinear: of the nearly 2,000 asylum appeals decided by the Ninth Circuit over the ten-year period from 1992 through 2001, all were brought by asylum seekers. As a matter of practice, the government does not seek judicial review of administrative asylum determinations.
} 
was observed between the number of Democratic appointees on a panel and the likelihood of publication; $;^{59}$ nor did undivided panels (those consisting entirely of Democratic or Republican appointees) publish more or less frequently than divided panels. ${ }^{60}$

Merritt and Brudney did report one finding that suggested the possibility of strategic judicial behavior: former management attorneys were significantly less likely to publish pro-union decisions. Such judges were also, however, more likely than others to vote on the merits in favor of unions. ${ }^{61}$ The authors deemed this combination of behavior unlikely to be strategic and attributed it instead to the "greater expertise" of former management attorneys in labor law, their "consequent ability to identify more decisions as routine," and the difficulty of distinguishing a general aversion to publication from a specific reluctance to publish pro-union decisions. ${ }^{62}$

Unexpected results were reached by Songer, Smith, and Sheehan in their study of the Eleventh Circuit. The authors found that Republicandominated panels were significantly more likely to publish their liberal decisions than were Democrat-dominated panels: majority-Republican panels published $80 \%$ of their liberal decisions, as compared to $57 \%$ for majority-Democrat panels. ${ }^{63}$ Consistent with other studies, ${ }^{64}$ however, Democratic panels were much likelier than Republican panels to reach liberal outcomes in their unpublished decisions. Consequently, notwithstanding the fact that Republican panels published a greater proportion of their liberal decisions, Democratic panels still published nearly five times as many liberal decisions as did Republican panels (297 to 62$).{ }^{65}$ Thus, their findings do not imply that a Republican panel would choose in a particular case to publish a liberal decision that a Democratic panel would not; rather, the Republican panel would be unlikely to reach a liberal decision in the first place. The authors do not purport to explain why Republican panels published a greater proportion of their liberal decisions, however, other than to suggest the possibility that "Republican judges feel obligated to clarify their reasoning"

59. See id. at 98-100, 99 tbl.VIII.

60. See id. at 103-07, 106 tbl.IX.

61. See id. at 99 tbl.VIII, 101-02.

62. Id. at 115. Merritt and Brudney describe the problem as one of "docket bias," which arises due to the combination of factors. Because most labor appeals are taken by employers, affirmances tend to favor unions and reversals tend to favor employers. However, because publication criteria tend to favor the publication of reversals, judges have more discretion over the publication of pro-union affirmances than over anti-union reversals. As a result, a general nonideological reluctance to publish may manifest itself as a reluctance to publish pro-union affirmances. See id.

63. See Songer et al., supra note 29, at 983 tbl.8.

64. See Merritt \& Brudney, supra note 8, at 107-11; Songer, supra note 23, at 311-12.

65. See Songer et al., supra note 29, at 983 tbl.8. 
when reaching outcomes that do not comport with their ideological preconceptions. ${ }^{66}$

\section{The Data: Asylum CaSes In The NinTH CirGuit, 1992-2001}

Judicial researchers have long been preoccupied with the Supreme Court, to the neglect of other courts that are equally deserving of study but lack the same cachet. ${ }^{67}$ Such distinctive phenomena as the use of randomly drawn panels, en banc rehearings, and selective publicationnot to mention the threat of reversal from above - demand the formulation of a research agenda specific to the federal courts of appeals. The Ninth Circuit merits particular attention for both substantive and methodological reasons: it is the nation's largest appeals court in terms of geographic size, number of judgeships, and volume of litigation, with jurisdiction over fifty million people and over a quarter of all pending federal appeals. ${ }^{68}$ These characteristics of size and scope make the Ninth Circuit not only intrinsically worthy of study, but also amenable to empirical analysis: the fact that it has more judges than any other federal court and oversees more than a fifth of all federal litigation makes for an abundance of data. If anecdotal evidence is to be believed, ideological behavior on the court is especially ripe for investigation: according to Judge Posner, "Ninth Circuit lawyers say (but not for attribution!) that more often than in any other federal court of appeals the composition of the panel determines the outcome of the appeal." ${ }^{\prime 69}$ Nonetheless, studies focused in whole or even in part on the Ninth Circuit remain rare. ${ }^{70}$

66. Id. at 983 .

67. See Lawrence Baum, The Puzzle of Judicial Behavior 126 (1997) (observing that scholarly emphasis on the Supreme Court has adversely limited attention to other courts); Martin Shapiro, Political furisprudence, in MARTIN Shapiro \& Alec StONe SweEt, ON Law, POlitics, AND JUdicialiZATION 19 (2002); David S. Law \& Sanford V. Levinson, Why Nuclear Disarmament May Be Easier to Achieve than an End to Partisan Conflict over fudicial Appointments, 39 U. RICH. L. REV. 923, 926-27 (2005).

68. See 2003 Annual Report of THE United States Courts For the Ninth CircutT 4, 20, available at http://www.ce9.uscourts.gov; ASHLYN K. KUERSTEN \& DONALD R. SONGER, DECISIONS ON THE U.S. COURTS OF APPEALS 14 (2001).

69. POSNER, supra note 15 , at 137.

70. Notable exceptions include work by Stephen Wasby, see, e.g., Wasby, supra note 10; Wasby, supra note 38; Stephen L. Wasby, "Extra" fudges in a Federal Appellate Court: The Ninth Circuit, 15 LaW \& Soc'Y REv. 369 (1980), and a series of studies by Arthur Hellman, sponsored in part by the Federal Judicial Center and by the Ninth Circuit itself, and addressed (explicitly or otherwise) to the ongoing policy debate over whether the court ought to be restructured or split. See Arthur D. Hellman, Dividing the Ninth Circuit: An Idea Whose Time Has Not Yet Come, 57 MONT. L. REV. 261 (1996); Arthur D. Hellman, Breaking the Banc: The Common-Law Process in the Large Appellate Court, 23 ARIZ. ST. L.J. 915 (1991) [hereinafter Hellman, Breaking the Banc]; Arthur D. Hellman, fumboism and Furisprudence: The Theory and Practice of Precedent in the Large Appellate Court, 56 U. CHI. L. REv. 541 (1989) [hereinafter Hellman, fumboism]; see also Robel, supra note 
The particular combination of asylum law and the Ninth Circuit invites empirical investigation for a variety of reasons. The fact that approximately three-quarters of asylum appeals are filed in the Ninth Circuit $^{71}$ — which translates into hundreds of appellate decisions on similar legal questions each year - promises adequate data for statistical analysis. This same category of cases also provides researchers with the opportunity to observe ideological disagreement among the judges. The treatment of asylum seekers is an area of law that divides the Ninth Circuit along ideological lines, a fact acknowledged by the judges themselves $^{72}$ and borne out by the data. Asylum cases implicate not simply technical questions of law and fact, but also such highly charged political issues as U.S. policy in Central America and the nation's receptivity to immigration. Disagreement in asylum cases may stem also from broader philosophical disagreement over the proper role of the federal courts vis-à-vis administrative agencies. As Hellman reports:

some judges, "out of exasperation or conviction," have come to accept the perception of the judiciary as having "a transcendent role as between the three branches of government." Others, while perhaps acknowledging that the Immigration and Naturalization Service is not a paragon among agencies, insist that it is not the judicial role to reverse every miscarriage of justice. ${ }^{73}$

The indeterminacy of the governing legal standards facilitates judicial disagreement. In a typical case, the underlying question is whether the petitioner has demonstrated a "well-founded fear of persecution" on political, ethnic, or religious grounds. Such determinations are made in the first instance within the Department of Justice, ${ }^{74}$ but are subject to review by the federal courts of appeals. A petitioner who has

\footnotetext{
53, at 946-49, 946 n.33 (discussing an unpublished 1988 report prepared for the use of the Ninth Circuit in assessing its limited publication plan).

71. See Interview with Former Immigration Judge Joe Vail (Dec. 5, 2003). During his time on the bench, Judge Vail, now a clinical faculty member at the University of Houston Law Center, earned the distinction of being one of the ten most lenient immigration judges toward asylum seekers in the country. See Fredric N. Tulsky, Uncertain Refuge: Asylum Seekers Face Capricious Legal System, SANJosE MERCURY News, Oct. 18, 2000, at 1A. Even relatively lenient immigration judges, however, grant only a minority of claims: Judge Vail's overall grant rate was $28 \%$, while the most lenient immigration judge, Lisa Dornell of Baltimore, had a grant rate of $35 \%$. See id.

72. See Hellman, Breaking the Banc, supra note 70, at 973-74; Telephone Interview with the Honorable Stephen Reinhardt, Circuit Judge, U.S. Court of Appeals for the Ninth Circuit, July 13, 2001; see also Hellman, fumboism, supra note 70, at 595-96 (noting that "underlying controversy over United States policy in central America" has contributed to "disarray" in the court's asylum decisions).

73. Hellman, Breaking the Banc, supra note 70, at 973-74 (quoting interviews conducted by Stephen Wasby with members of the Ninth Circuit).

74. See National Association of Immigration Judges, An Independent Immigration Court: An Idea Whose Time Has Come (Jan. 2002), available at http:/ / images.latimes.com/media/acrobat/2002-01 / 1848706.pdf.
} 
demonstrated a "well-founded fear" is statutorily eligible for asylum ${ }^{75}$ and the case must then be remanded to the Attorney General, who has discretion whether to grant asylum. ${ }^{76}$

The court may go further, however, and determine it is "more likely than not" that the petitioner will face persecution if deported. Such a finding entitles the petitioner to a heightened form of relief called withholding of deportation, which means not only that the petitioner is eligible for asylum, but also that the petitioner cannot be deported regardless of whether the Attorney General decides to grant asylum. ${ }^{77}$ It is left for judges to define vague yet crucial terms - "political," "persecution," "well-founded fear," "more likely than not"- on a case-by-case basis. Precedent provides only limited guidance, given the dependence of asylum claims on case-specific facts.

The fact-intensive yet ideologically divisive nature of asylum cases should have several empirical consequences. First, for both legal and strategic reasons, such cases should be published less frequently than other types of appeals. The factually driven, legally repetitious nature of asylum appeals would seem to make them poor candidates for publication on the whole, as does the fact that the administrative asylum determinations being appealed are themselves invariably unpublished. Insofar as asylum appeals are unlikely to involve the elucidation of new legal rules or the reversal of published decisions, the formal criteria governing publication do little to encourage their publication. ${ }^{78}$ Moreover, strategically minded judges who wish to maximize the precedential effect of their published opinions may prefer to focus their time and effort upon less fact-intensive areas of law instead. The data are at least consistent with these predictions: the publication rate for asylum appeals in the Ninth Circuit is approximately half the overall publication rate. ${ }^{79}$ Second, however, any variations observed between the

75. See 8 U.S.C. $\$ 1101(\mathrm{a})(42)(\mathrm{A})(2000)$.

76. In practice, the Attorney-General routinely grants asylum to those who have been found eligible. See Vail, supra note 73.

77. See, e.g., Chanchavac v. INS, 207 F.3d 584, 592-93 (9th Cir. 2000); Vallecillo-Castillo v. INS, 121 F.3d 1237, 1240 (9th Cir. 1996). Those who can demonstrate past persecution are also presumptively entitled to withholding of deportation. See, e.g., Hernandez-Montiel v. INS, 225 F.3d 1084, 1099 (9th Cir. 2000); Vallecillo-Castillo, 121 F.3d at 1240. For examples of cases in which a petitioner was found eligible for asylum, but not entitled to withholding of deportation, see $\operatorname{Lim} v$. INS, 224 F.3d 929, 934, 937-38 (9th Gir. 2000), and Nufio-Perdomo v. INS, No. 97-70906, 1999 U.S. App. LEXIS 1434, at*3-*4 (9th Cir. Jan. 29, 1999) (mem.). Not every decision, however, draws a clear distinction between the requirements for mere asylum eligibility and those for withholding of deportation. See, e.g., Martirosyan v. INS, 229 F.3d 903, 909 (9th Cir. 2000) (granting withholding of deportation because the requirements for asylum eligibility had been met).

78. See, e.g., 9TH CIR. R. 36-2; infra text accompanying note 89 (discussing 9TH CIR. R. 36-2).

79. The overall publication rate in the Ninth Circuit is approximately $15 \%$. See Administrative Office of the U.S. Courts, Federal Court Management Statistics 2003, available at http://www.uscourts.gov/ cgi- 
voting and publication patterns of Republican and Democratic judges in the asylum context are likely to be the product of ideological differences. Even if there are legal reasons to expect lower publication rates in the asylum context, the law provides no reason for Republicans and Democrats to publish at different rates, for example, or to vote differently in the cases that they do publish.

Indeed, as Hellman acknowledges, the very difficulty of justifying publication in the asylum context on objective grounds invites an ideological or strategic explanation as to why judges would publish at all:

$[\Pi \mathrm{t}$ is difficult to justify the publication of numerous opinions that do little more than point to the facts that persuaded the judges to put the case on one side of the line rather than the other. One possible explanation is that the judges in each camp are attempting (perhaps unconsciously) to stake out the largest possible territory and to preempt other panels from enlarging the terrain controlled by precedents favoring their approach. ${ }^{80}$

Accordingly, to investigate the relationship between judicial ideology and publication, I coded for analysis all asylum decisions filed by the Ninth Circuit over a ten-year period beginning in 1992. The data were assembled by searching LexisNexis for all Ninth Circuit decisions containing the word "asylum" 81 and winnowing down the results. I eliminated all cases that had nothing to do with asylum, cases in which the government conceded, and atypical cases that did not pose any of the core substantive or procedural questions on which eligibility for asylum ordinarily depends. ${ }^{82}$ I also excluded en banc decisions, of which there were only three in total. Although such cases are valuable sources of data in other contexts, they were not suitable for analysis here for the simple reason that they are always published. The resulting data set of 1,892 cases includes 143 published decisions.

The ten-year period from 1992 through 2001 was well-suited to empirical analysis for a variety of reasons. The period is sufficiently recent that electronic coverage of unpublished decisions is comprehensive. The fact that the period coincides with the Clinton presidency

\footnotetext{
bin/cmsa2003.pl (last visited Feb. 21, 2004). By comparison, only 7.7\% of the asylum cases decided by the Ninth Circuit over the ten-year period studied here were published.

80. Hellman, Breaking the Banc, supra note 70, at 974.

81. Although LexisNexis does not guarantee comprehensive coverage of unpublished circuit court opinions, its representatives indicate that every effort is made to include all of them, and that, for the time period and court in question, there is no reason to think that any would have been omitted.

82. Those eliminated included, for example, cases that turned on interpretation of newly enacted jurisdictional statutes, or on whether the appellant had committed a "serious crime" that rendered him or her statutorily ineligible for asylum. For a similar approach to the elimination of atypical cases, see Merritt \& Brudney, cited above in note 8, at 80-81.
} 
(with an extra year on each end) also facilitates the investigation of research questions beyond the scope of this paper. More drastically than any other circuit, the Ninth Circuit transformed during the study period from a solidly Republican court to a solidly Democratic one under President Clinton. ${ }^{83}$ A 1992-2001 data set enables future examination of the impact both of changes in partisan control and of President Clinton's appointees in particular. Most importantly, there were no major changes in substantive asylum law between 1992 and 2001 that would confound any efforts to explain changes in judicial behavior on behavioral or strategic grounds. The Clinton years saw effectively no change in Supreme Court precedent respecting the substantive standards for the granting of asylum or withholding of deportation. $^{84}$ A Westlaw search reveals only 16 Supreme Court opinions from 1992 through 2001 that even contain the word "asylum." Of these cases, the majority either have nothing to with asylum or concern jurisdictional questions posed by federal statutes or extradition treaties; only three were arguably relevant to the substantive standards governing the granting of relief to asylum applicants. Two of these cases were decided at the very beginning of 1992 and thus were already binding on the Ninth Circuit for all but two or three weeks of the entire study period. ${ }^{85}$ The third was not decided until May 1999 and appears to have affected the outcome of only one Ninth Circuit decision in the study period. ${ }^{86}$

83. See infra Figure 1.

84. A pair of federal statutes - the Anti-Terrorism and Effective Death Penalty Act of 1996 (AEDPA), and the Illegal Immigration Reform and Immigrant Responsibility Act of 1996 (IIRIRA)included provisions that curtailed the availability of asylum and judicial review for convicted felons and suspected terrorists facing deportation. Both statutes also introduced restrictive changes to the asylum application process. See Anti-Terrorism and Effective Death Penalty Act of 1996, Pub. L. No. 104-132, §§ 421-23, 110 Stat. 1214, 1270-73 (codified as amended in scattered sections of 8 U.S.C.); Illegal Immigration Reform and Immigrant Responsibility Act of 1996 § 604, 8 U.S.G. § 1158 (2000 \& Supp. II 2002). Neither statute, however, purported to modify the substantive legal standards governing eligibility for asylum. Cases that turned on the interpretation or application of either statute were excluded from the data.

85. INS v. Doherty, 502 U.S. 314 (1992); INS v. Elias-Zacarias, 502 U.S. 478 (1992). Doherty concerned the standards governing the denial of a motion to reopen deportation proceedings, see 502 U.S. at 314-29, which are only indirectly related to the standards governing actual adjudication of an asylum claim. Denial of a motion to reopen is a procedural ruling that, unless overturned, can prevent the asylum claimant from making an actual request for asylum or withholding of deportation. A motion to reopen is necessary only when the asylum claimant has committed some procedural default (for example, by failing to make his or her claim at the initial deportation hearing). See id. at 318-22. Elias-Zacarias, by contrast, is considered the "seminal" Supreme Court decision on the standards governing asylum adjudication. Chand v. INS, 222 F.3d 1066, 1078 (9th Cir. 2000). It concerned the substantive question of what constitutes persecution on account of political opinion, and directed the lower courts to uphold denials of asylum absent evidence "so compelling that no reasonable factfinder could fail to find the requisite fear of persecution." Elias-Zacarias, 502 U.S. at 484.

86. INS v. Aguirre-Aguirre, 526 U.S. 415 (1999), reversed a Ninth Circuit panel decision on the question of when someone has committed a "serious nonpolitical crime" that jeopardizes one's eligibility 
Nor did the ideological composition of the Supreme Court change between 1992 and 2001 in a manner that would have given Ninth Circuit judges reason to tread more carefully (or aggressively) in asylum cases. ${ }^{87}$

\section{Publication Rules and Practices in the Ninth Circuit}

The average active Ninth Circuit judge authors approximately 150 decisions per year, roughly $15 \%$ of which are published. ${ }^{88}$ In the Ninth Circuit, Rule 36-2 sets forth the criteria that judges are supposed to apply in deciding whether to publish a decision. It provides that a decision should be published only if it:

(a) Establishes, alters, modifies or clarifies a rule of law, or

(b) Calls attention to a rule of law which appears to have been generally overlooked, or

(c) Criticizes existing law, or

(d) Involves a legal or factual issue of unique interest or substantial public importance, or

(e) Is a disposition of a case in which there is a published opinion by a lower court or administrative agency, unless the panel determines that publication is unnecessary for clarifying the panel's disposition of the case, or

(f) Is a disposition of a case following a reversal or remand by the United States Supreme Court, or

(g) Is accompanied by a separate concurring or dissenting expression, and the author of such separate expression requests publication of the disposition of the Court and the separate expression. ${ }^{89}$

\footnotetext{
for withholding of deportation. This question does not arise in most asylum cases; rather, the vast majority of asylum cases in the Ninth Circuit usually turn on whether someone has demonstrated a "well-founded fear of persecution." Over the 1999-2001 period, Ninth Circuit decisions cited Aguirre-Aguirre 34 times. In only one of those cases did an asylum claimant actually appear to have lost due in whole or in part to the Supreme Court's decision in Aguirre-Aguirre. See Ahmed v. INS, No. 97-71313, 1999 U.S. App. LEXIS 30174 (9th Gir. Nov. 18, 1999). The remainder either distinguished Aguirre-Aguirre or cited it for general propositions relating to standards of review or the deference owed administrative interpretation of statutes.

87. The two personnel changes on the Court since 1992 have consisted of the replacement of a liberal (Blackmun) and a moderate (White) by two moderate-liberals (Ginsburg and Breyer). See Simon Jackman, Bayesian Analysis for Political Research, 7 ANN. REV. POL. SCI. 483, 499-502 (2004) (estimating the relative ideological positions of Supreme Court justices on the basis of their voting records); Michael Bailey \& Kelley H. Chang, Comparing Presidents, Senators, and fustices: Interinstitutional Preference Estimation, 17 J.L. ECON. \& ORG. 477, 491, 495 (2001) (same).

88. See Administrative Office of the U.S. Courts, supra note 79 (providing summary statistics, by circuit and year, of the number of written decisions per judge, both "signed" (published) and "unsigned" or "without comment" (unpublished)).

89. 9TH GIR. R. 36-2. In the court's nomenclature, a published decision is called an "opinion," while an unpublished decision is called a "memorandum decision," or "memdispo" for short. See Wasby, supra note 38 , at 332-35.
} 
The rules do not specify whether publication ordinarily requires unanimity, a majority, or merely a single judge in favor. ${ }^{90}$ Normal practice is apparently to defer to the author of the decision. ${ }^{91}$ Nor do the rules specify when the decision to publish is to be reached: judges' accounts suggest that it is made initially at conference - the meeting at which the judges cast their initial votes on the merits - but is subject to later revision, as are the judges' votes. ${ }^{92}$ The panel can entertain, but is not obligated to grant, requests for publication from the litigants or from other members of the court. ${ }^{93}$ In addition, clause (g) of Rule 36-2 empowers any member of the panel who has authored a separate concurring or dissenting opinion to force publication, but it is not obvious why a judge who rejects the majority's decision would seek to turn it into binding precedent.

The interaction between publication and voting is potentially complex, for various reasons. First, each may influence the other. For example, a judge who is in the ideological minority can threaten to dissent if a case is published, or agree to go along with the majority so long as the case remains unpublished. In such a case, the majority's decision on publication directly influences the minority judge's vote. If the threat to dissent actually dissuades the authoring judge from choosing to publish, however, then voting can also be said to influence publication. Second, both the decision whether to publish and the judges' votes on the merits can be revisited any number of times. If the authoring judge changes her mind on the question of publication, the other judges are free to respond by changing their votes - in response to which the authoring judge may again revisit the question of publication, and so on, ad infinitum. ${ }^{94}$

Notwithstanding the possibility of cycling, however, the question of publication must be resolved before voting can be finalized. Judges always know whether a decision will be published before voting is settled once and for all: the authoring judge cannot publish by surprise, and judges can choose to write concurring or dissenting opinions in response

\footnotetext{
90. Publication of an order, as opposed to a decision, requires a majority in favor. See 9TH CIR. R. $36-5$.

91. See Wasby, supra note 38, at 333-36; see also supra note 38 (citing practices in other circuits).

92. See Wasby, supra note 38, at 333-36; see also supra note 38 (citing practices in other circuits); Martin, supra note 16, at 187-88; Nichols, supra note 19, at 915.

93. See Wasby, supra note 38 , at 335 .

94. Cycling of this kind should not occur as long as the authoring judge can anticipate the effect of publication on the other judges' votes. If the authoring judge can foresee whether publication (or failure to publish) would jeopardize majority support for her decision — or even provoke a dissent that would lead her to reconsider publication-she can refrain from causing the problem at the outset.
} 
to a decision to publish. The last move in the game, as it were, always belongs to all members of the panel as they choose how to vote.

\section{HYPOTHESES}

The questions explored in this Article concern the effects of ideology on judicial behavior. The ideology in question might be described broadly as a greater willingness on the part of judges selected by Democratic presidents $^{95}$ to suspect government agencies of unresponsiveness, indifference, and perhaps even callousness toward powerless individuals. In the particular context of asylum, this ideology might comprise solicitude for individuals who have fled for their lives to the United States, only to find themselves in detention centers, unable to afford adequate counsel or even to speak English, and forced to contend with immigration authorities hardly renowned for their expeditiousness, sensitivity, or generosity. ${ }^{96}$ The corresponding attitude in Republican appointees might be characterized as a combination of a general faith in the bona fides of agency action, a philosophical preference for minimal judicial interference with the actions of the other branches, and skepticism developed over time as to the veracity of large numbers of petitioners who bring similar asylum claims with little or no external corroboration.

1. Ideology influences judicial voting in unpublished cases. Some researchers assume that unpublished cases may safely be ignored because they are straightforward cases that leave little room for ideological disagreement. For example, in their study of ideological voting on the courts of appeals, Sunstein, Schkade, and Ellman exclude unpublished cases from their analysis on the ground that they seek only to "test the role of ideology in difficult cases rather than easy ones." "As a general rule," they assert, "unpublished opinions are widely agreed to be simple and straightforward, and to involve no difficult or complex issues of law.",98 Another knowledgeable observer has bluntly described unpublished

95. Studies of judicial behavior have, consistently and with success, used party of appointing president as a proxy for judicial ideology. See Frank B. Cross, Decisionmaking in the U.S. Circuit Courts of Appeals, 91 CaL. L. Rev. 1459, 1479 (2003) (citing examples).

96. See, e.g., Fredric N. Tulsky, Despite Tales of Horror, Court Kept Many Refugees Behind Bars, SANJosE Mercury News, Oct. 18, 2000, at 21A; Fredric N. Tulsky, Asylum Seekers Face Tougher U.S. Laws, Attitudes, San Jose Mercury News, Dec. 10, 2000, at 1A; Fredric N. Tulsky, Power Granted INS Inspectors to Deny Entry Sparks Concem, SANJose MERCURY News, Dec. 10, 2000, at 18A.

97. See Cass R. Sunstein et al., Ideological Voting on Federal Courts of Appeals: A Preliminary Investigation, 90 VA. L. REV. 301, 313 (2004).

98. Id. 
decisions as "less important," on the assumption that they are "only infrequently used for reversals." 99

As noted above, past studies have rejected the notion that unpublished cases are "easy" ones that cannot be expected to divide judges along ideological lines. ${ }^{100}$ Not only do Democratic and Republican appointees tend to vote differently in unpublished cases, but the magnitude of the disparity has been found to be comparable across published and unpublished cases. This Article seeks to replicate these findings using the entirely new data set described above.

It has been found, however, that the true extent to which judges divide along ideological lines is masked by panel composition effects. ${ }^{101}$ That is, a lone Republican sitting with two Democrats votes more liberally than if paired with one or more fellow Republicans; similarly, a lone Democrat sitting with two Republicans votes more conservatively than if paired with one or more fellow Democrats. It remains an open question whether this phenomenon occurs because majority judges modify their behavior in response to the presence of a minority judge, because minority judges accommodate themselves to majorities, or due to some combination of the two. In either case, ideological voting patterns have been found only when judges have likeminded colleagues with whom they constitute majorities. The voting records of individual judges, viewed in isolation, do not capture the full extent of ideological division. Accordingly, the hypotheses to be tested here focus upon the effect of panel composition on case outcomes, not the voting records of individual judges.

Hypothesis 1(a). The composition of the panel will have a significant effect on the outcome of published and unpublished cases alike. Panels dominated by Democratic appointees will be significantly more likely than those dominated by Republican appointees to reach decisions that favor asylum seekers, regardless of publication.

Hypothesis 1(b). Unpublished cases are as ideologically divisive as published cases. Thus, panel composition will affect outcomes as strongly in unpublished cases as in published cases.

2. Ideology influences the decision to publish. The accounts of such prominent jurists as Judge Wald and Judge Arnold, as well as the author's

99. See Wasby, supra note 70, at 382 (concluding that senior judges on the Ninth Circuit are not "regularly given less important tasks," in light of the finding that they participate more often in published than in unpublished rulings).

100. See supra note 45 and accompanying text (citing studies by Merritt and Brudney, Songer, and others).

101. See supra note 44 (discussing studies by Cross and Tiller and Revesz). 
own observations as a law clerk on the Ninth Circuit, ${ }^{102}$ provide grounds to suspect that circuit judges prefer to publish decisions they favor on ideological grounds, and to minimize the impact of ideologically disfavored decisions by leaving them unpublished. Yet as discussed above, no study to date has uncovered significant evidence of what might be called strategic judicial lawmaking on the courts of appeals.

Two types of strategic behavior might be expected - one on the part of judges who are in the ideological majority on a panel, and the other on the part of judges who find themselves in the ideological minority. Majority judges may seek both to publish decisions that they support on ideological grounds, and to leave unpublished cases in which they find themselves compelled to reach ideologically undesirable results. Minority judges, on the other hand, may threaten to dissent as a means of discouraging publication, while agreeing to go along with the majority if the decision remains unpublished. In both cases, the same correlation should be observed between publication and voting on the merits: publication will amplify the ideological propensity of a judge to vote for or against asylum seekers.

Conversely, judges will show greater willingness to vote against their ideological convictions in unpublished cases. Because unpublished cases do no damage as precedent, a minority judge who would prefer to decide the case differently may trade her vote in return for nonpublication or acquiesce for the sake of "collegiality," which may include a meaningful expectation of reciprocity over the course of repeat play. Meanwhile, majority judges will prefer not to publish decisions that, if given precedential force, would work against the state of the law that they prefer. The net result will be that Democratic appointees will show a greater tendency to vote in favor of asylum in published cases than in unpublished cases, while Republican appointees will show the opposite tendency.

Hypothesis 2(a). Democratic panels are significantly more likely than Republican panels to publish pro-asylum decisions, and to leave anti-asylum decisions unpublished.

Hypothesis 2(b). Publication induces sincere voting on the part of individual judges: it increases the propensity of Democratic appointees to vote in favor of asylum, but has the opposite effect on Republican appointees.

Insofar as judges publish for ideological reasons, one might further hypothesize that the presence of a minority judge on a panel discourages

102. It is presumably a matter of public record that the author clerked for Judge Reinhardt from 1996 to 1997. The reader would, however, be mistaken to infer from this fact that Judge Reinhardt himself engaged in the strategic behavior explored here. See infra Table 3 and accompanying text. 
publication by the majority. As previously noted, studies have shown that judges on undivided panels vote more ideologically than those on divided panels. ${ }^{103}$ It may be that, for similar reasons, judges on undivided panels publish more aggressively in the absence of a minority judge who might discourage publication. There are two reasons why a minority judge might dampen the tendency of a panel to publish. First, the presence of a minority judge may affect the quality of deliberation and thereby lead the majority judges to moderate their views. ${ }^{104}$ In the context of publication, a minority judge may act as a voice of reason and persuade the other panel members that publication is unnecessary. Second, as suggested above, strategically minded minority judges may offer to vote with the majority in exchange for nonpublication.

In their study of unfair labor practice appeals, Merritt and Brudney tested the hypothesis that panel homogeneity influences publication, and found no evidence to support it. ${ }^{105}$ Nevertheless, the hypothesis merits repeat exploration here, in the context of data drawn from a different area of law and a reputedly divided court.

Hypothesis 2(c). The presence of a minority judge, who may moderate the viewes of the majority or engage in strategic bargaining, dampens the tendency of divided panels to publish, relative to undivided panels.

3. The likelihood of reversal influences the decision to publish. Unpublished cases are less likely than published cases to attract reversal, either en banc or by the Supreme Court. ${ }^{106}$ This fact should come as little surprise: it makes little sense for judges to spend scarce resources monitoring decisions that have no precedential value. Leaving cases unpublished is thus a way for strategically minded judges to avoid reversal. They may choose not to publish decisions that they feel are especially vulnerable to reversal; conversely, if the risk of reversal is low, they may feel emboldened to publish decisions that they otherwise might not. If judges do take into account the likelihood of reversal when

103. See Cross \& Tiller, supra note 44, at 2168-76 (discussing the "whistleblower" hypothesis); supra text accompanying note 101 ; supra note 44 .

104. Revesz, supra note 44, at 1732-34 (articulating "deliberation hypotheses"); Cross \& Tiller, supra note 44, at 2159 (suggesting that a minority judge may "caus [e] the majority to acknowledge its disregard or unintentional manipulation of doctrine").

105. See supra note 60 and accompanying text.

106. See Hannon, supra note 20, at 225-31, 241 app.A (documenting the relative rarity of Supreme Court review of unpublished opinions); Bergeron, supra note 13, at 794-96 (finding, on the basis of empirical analysis, that en banc review of unpublished decisions is extremely rare); POSNER, supra note 15, at 165 ("The judge knows that an unpublished opinion . . . will be largely immune from professional criticism because there is little interest in opinions that are not published and citable."). 
deciding whether to publish, ${ }^{107}$ their willingness to publish should be affected by factors that influence the likelihood of reversal.

The composition of the full court is one such factor. In the Ninth Circuit, en banc rehearing does not occur unless a majority of the court's active judges votes in favor of it. If the vote is successful, the case is reheard by an eleven-judge panel consisting of the chief judge and ten others drawn at random from the active membership of the court. ${ }^{108}$ An "outlier" panel consisting of judges drawn from the ideological minority of the court may thus have reason to fear reversal en banc if it chooses to publish: the more ideologically unfriendly judges there are on the full court, the more likely that a majority of the court will vote to rehear the case en banc, and the more unfriendly that the en banc panel itself is likely to be.

Between 1992 and 2001, the balance of the Ninth Circuit shifted decisively in favor of Democratic appointees, as illustrated by Figure 1 below. When Clinton took office, Republican appointees constituted a 15 to 13 majority of the Ninth Circuit's active judges. Moreover, the imbalance in favor of Republican appointees actually worsened through most of Clinton's first term: by the beginning of 1996, the court's active Democratic judges were outnumbered 15 to 10. By the time Clinton left office, however, he had filled half of the circuit's 28 judgeships.

107. Cf. Wald, supra note 13 , at 503 (" $[\Pi \mathrm{t}$ is proper in my view, and certainly strategically wise, for a panel to take account of what the full court assembled might decide en banc and to cast its decision in a way that it believes would survive that review."); $i d$. at 501 (observing that judges sometimes evade precedents they dislike by issuing unpublished decisions).

108. A minor exception exists for senior judges of the court who participated in the original panel decision: they may choose to be eligible to be drawn for membership on the en banc panel. See 9TH CIR. R. 35-3 advisory committee's note. 
Figure 1: The shifting balance of power on the Ninth Circuit

\section{Impact of Clinton appointments, 1992-2001}

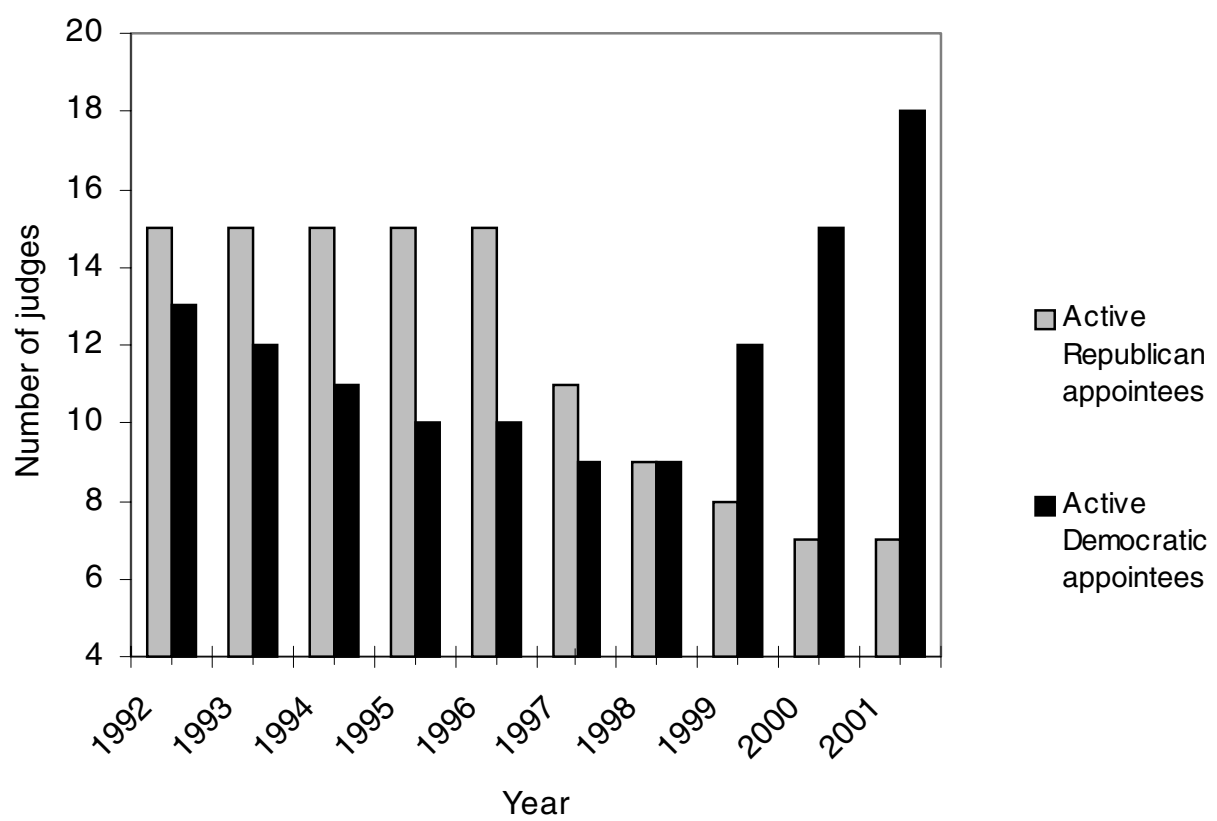

If willingness to publish responds to changes in the likelihood of reversal, the change in the composition of the court should have emboldened Democratic panels to publish pro-asylum opinions, while deterring Republican panels from publishing anti-asylum opinions.

There are reasons to doubt, however, whether the risk of en banc reversal looms large in the calculations of strategically minded judges, particularly in the asylum context. En banc review is a rarity. Fewer than $1 \%$ of cases in the courts of appeals are resolved en banc. ${ }^{109}$ Asylum decisions, in particular, appear to face even slimmer odds: in the present data set, out of the nearly 1,900 asylum cases decided over ten years, only three were heard en banc. This infrequency is unsurprising insofar as asylum cases seem to constitute unattractive candidates for en banc rehearing: because they typically involve the fact-intensive application of an open-ended legal standard, they offer only limited opportunities for the enunciation of broad legal rules of the kind that

109. See George, supra note 13, at 214 \& n.5. 
justify the large expenditures of judicial effort demanded by the en banc procedure.

With these caveats in mind, one might nevertheless hypothesize that judges modify their publication behavior in response to changes in the likelihood of reversal en banc.

Hypothesis 3(a). Changes in the ideological balance of the full court affect the willingness of judges to publish opinions that they favor. Thus, the shift that occurred under the Clinton administration from Republican to Democratic control of the full court should have emboldened Democratic panels to publish pro-asylum opinions, while discouraging Republican panels from publishing anti-asylum opinions.

One might also hypothesize that ideologically motivated judicial publication behavior responds to changes in the likelihood of Supreme Court reversal. A leftward shift in the Supreme Court, for example, might be expected to embolden Democratic panels to publish proasylum decisions, while discouraging Republican panels from doing the contrary. This hypothesis, too, is doubtful. Again, review is a rarity, and a number of judges - members of the Ninth Circuit included - have specifically questioned the extent to which review by the Supreme Court of a miniscule proportion of cases can be expected to influence circuit court decisionmaking. ${ }^{10}$ In any event, however, the present data set offers no opportunity to test this hypothesis. As noted above, there were no meaningful changes in the ideological composition of the Supreme Court between 1992 and 2001 that would permit the isolation of such an effect on publication behavior. ${ }^{11}$ Moreover, as previously discussed, the Supreme Court has not taken an active interest in asylum cases. ${ }^{112}$ Nor does it have much reason to invest its own scarce resources in this area of law, for the same reason that asylum cases are unattractive candidates for en banc rehearing: the question of eligibility for asylum hinges upon the fact-specific application of a statutory standard of reasonableness that additional verbal formulation by a reviewing court is unlikely to clarify decisively. Accordingly, the hypothesis is merely articulated here for future research.

Hypothesis 3(b). Changes in the ideological composition of the Supreme Court affect the willingness of circuit judges to publish opinions that they favor. A leftward shift in the ideological balance of the Supreme Court will increase the frequency with which Democratic panels publish liberal decisions, and decrease the

110. See Cross, supra note 95, at 1485-87 (quoting, among others, Ninth Circuit Judges Jerome Farris and Stephen Reinhardt).

111. See supra note 87.

112. See supra text accompanying notes 84-86. 
Law:

frequency with which Republican panels publish conservative decisions. A rightward shift by the Court will have the opposite effect.

\section{FINDINGS}

1. Ideology significantly influenced the outcomes of both published and unpublished cases. Both hypotheses 1(a) and 1(b) were easily confirmed. MajorityDemocratic panels were significantly more likely than majorityRepublican panels to grant some form of relief to asylum seekers. Moreover, this difference was pronounced in both published and unpublished cases. With respect to unpublished cases, majority-Democratic panels granted relief $20.5 \%$ of the time, while majority-Republican panels did so just $7.5 \%$ of the time. In other words, Democratic panels were 2.7 times more likely than Republican panels to rule in favor of the asylum seeker. By comparison, in published cases, Democratic panels granted some form of relief nearly three-quarters of the time, while Republican panels did so less than half of the time. In both contexts, the difference between Democratic and Republican panels was statistically significant at the $\mathrm{p}<.001$ level, per a two-sample test of proportions. Figures 2 through 5 illustrate these findings. ${ }^{113}$

113. Cases labeled "petition denied" were those in which the asylum seeker received no relief whatsoever. Cases labeled "petition granted" were those in which the asylum seeker received any kind of relief on either substantive or procedural grounds, while "withholding granted" denotes cases in which the petitioner was granted the strongest form of relief available, withholding of deportation. 
Figure 2: Outcomes of unpublished decisions by Democratic panels

\section{Unpublished decisions: Democratic panels $(\mathbf{n = 8 0 4})$}

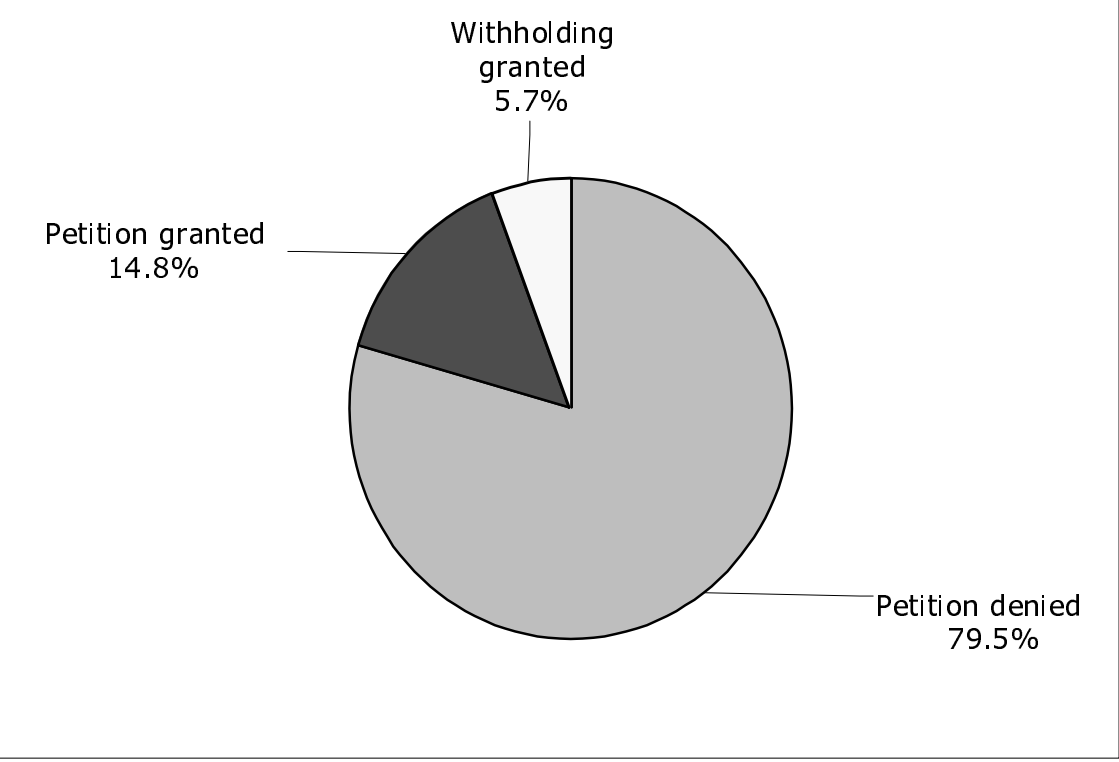


Figure 3: Outcomes of unpublished decisions by Republican panels

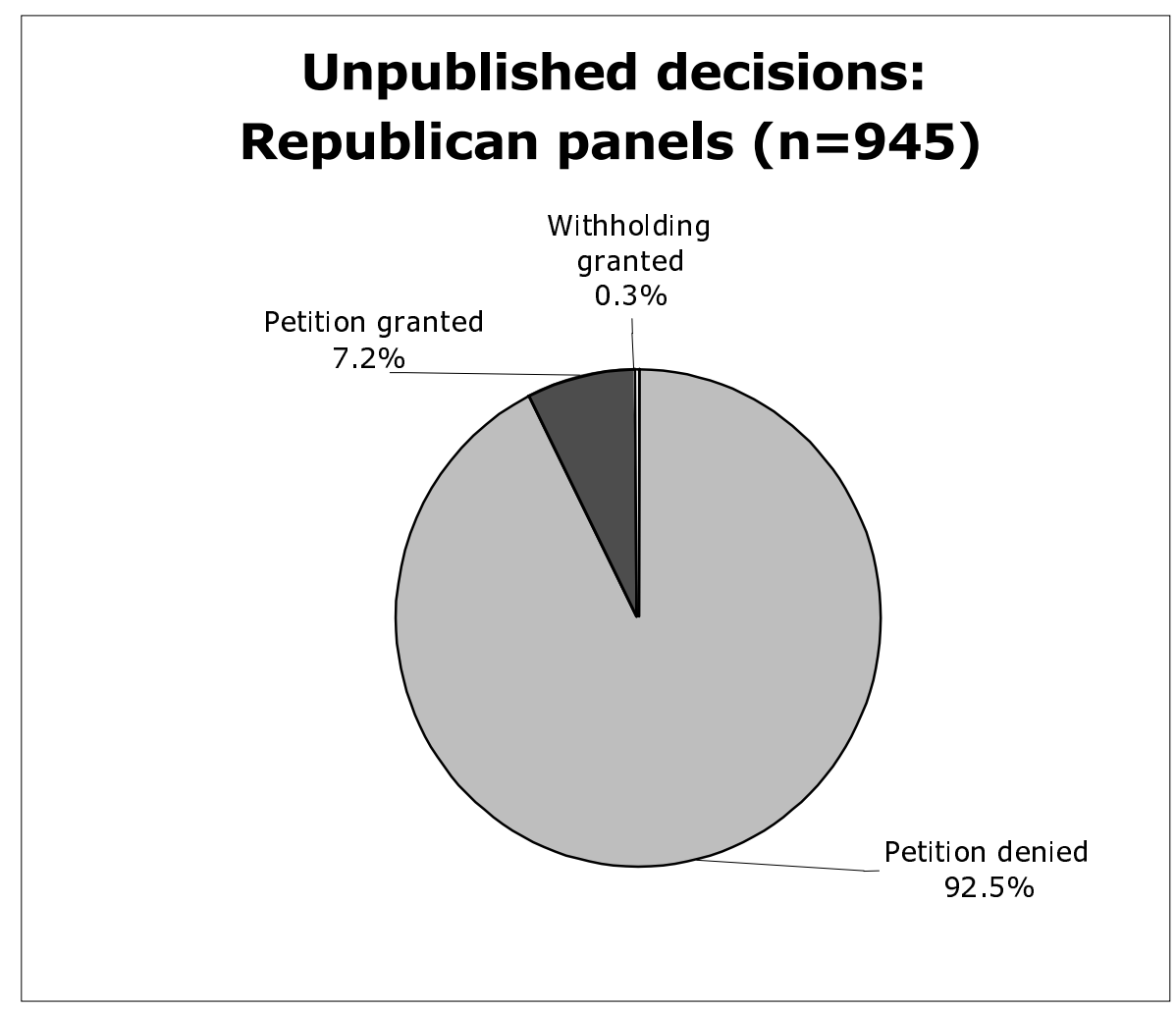


Figure 4: Outcomes of published decisions by Democratic panels

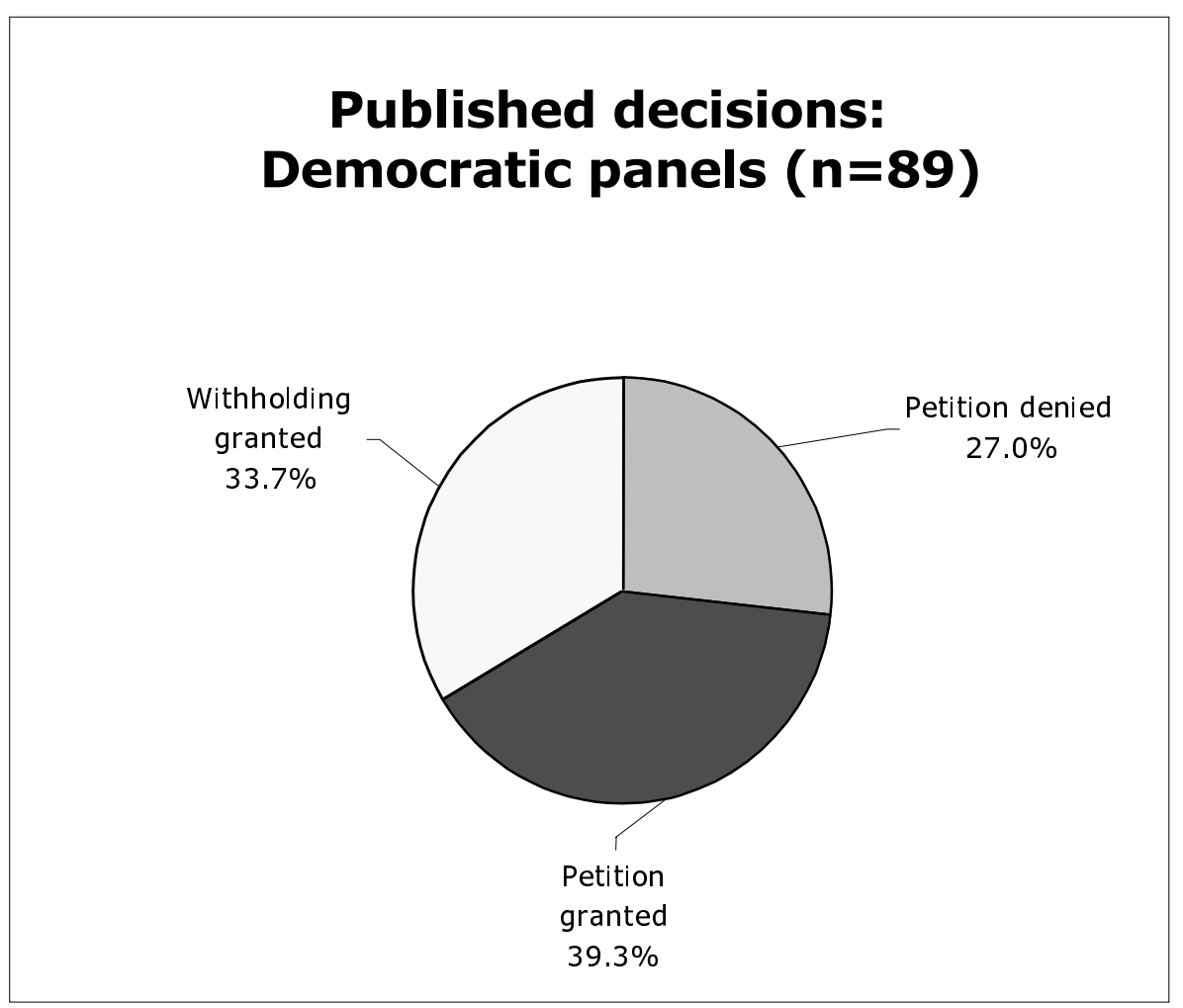


Figure 5: Outcomes of published decisions by Republican panels

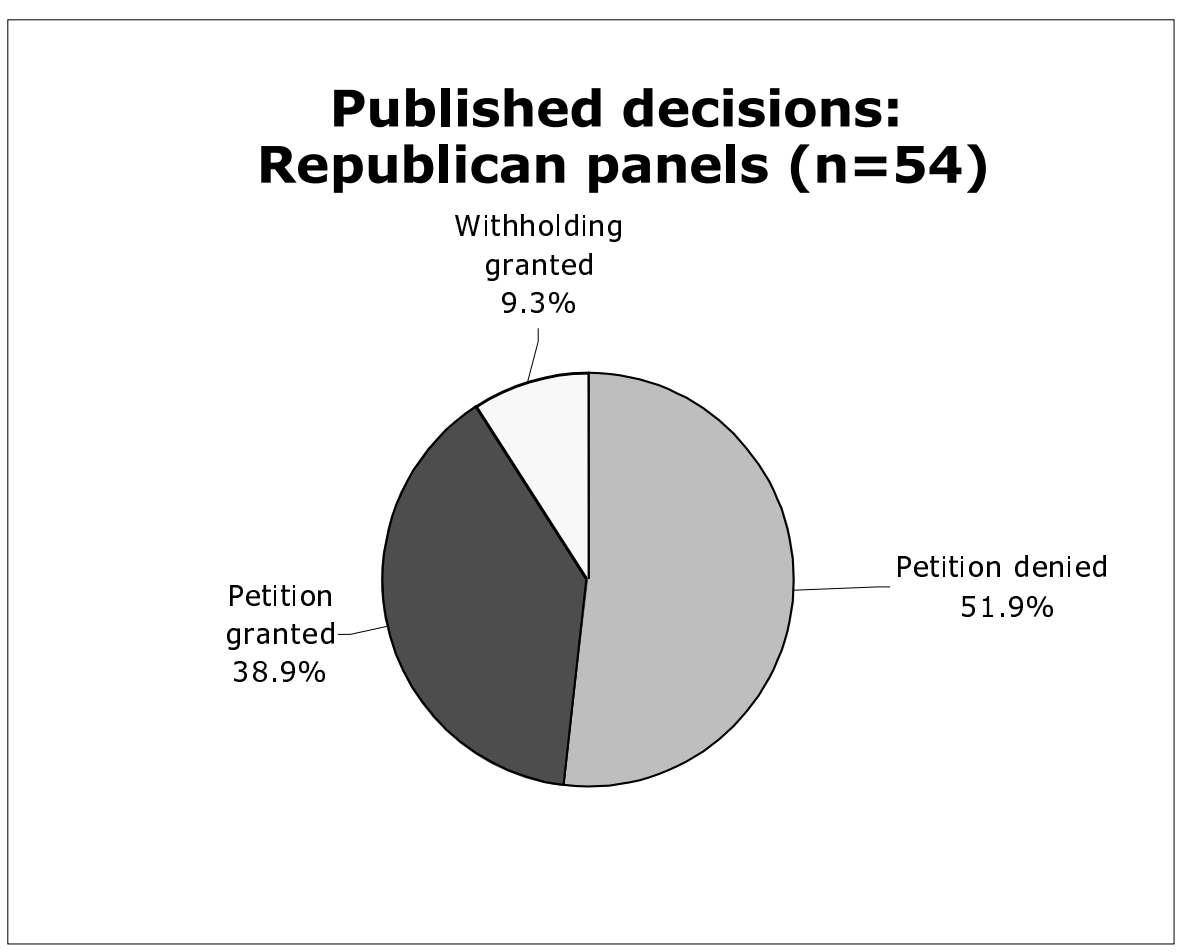

Logistic regression confirms the effect of panel composition on the outcome of unpublished cases. The probability of a pro-asylum decision was treated as a function of the number of Democratic appointees on the panel (Model 1). For each of the three judges on a panel, a binary indicator was coded, either 0 for those appointed by Republican presidents or 1 for those appointed by Democratic presidents. These three indicators were then used in a logistic regression to predict the actual outcomes of unpublished cases. As shown by the table below, all three proved to be highly significant predictors of how unpublished asylum cases were decided. In substantive terms, the probability of a proasylum decision jumps significantly with each additional Democratic appointee on the panel. ${ }^{114}$ With an all-Republican panel, the likelihood that an unpublished decision will favor the asylum seeker is just $4 \%$.

114. Predicted probabilities and their accompanying standard errors were generated in Stata 8.2 using the Clarify macro set, available for download at http:/ / gking.harvard.edu/stats.shtml (version 2.1, Jan. 5, 2003). For an introduction to Clarify and the simulation methods it employs, see Gary King et al., Making the Most of Statistical Analysis: Improving Interpretation and Presentation, 44 AM.J. POL. SCI. 347, 347-61 (2000). 
The addition of one Democrat to the panel triples that probability to $12 \%$. With two Democrats on the panel, the probability increases again to just over $20 \%$, and with an all-Democrat panel, the asylum seeker's chances top $30 \%$.

Model 1: Using panel composition to predict outcome

$\operatorname{Pr}($ pro-asylum decision $)=\alpha+\beta_{1}\left(\right.$ party $\left._{\text {judge } 1}\right)+\beta_{2}\left(\operatorname{party}_{\text {judge } 2}\right)+\beta_{3}\left(\operatorname{party}_{\text {judge } 3}\right)$

Table 1: The Effect of Panel Composition on Outcome in Unpublished Cases

\begin{tabular}{ll}
\hline Predictor variable & $\begin{array}{l}\text { Estimate of } \beta \\
\text { (standard error) }\end{array}$ \\
\hline Party of judge 1 & $1.19^{* *}$ \\
& $(0.161)$ \\
Party of judge 2 & $0.61^{* *}$ \\
& $(0.144)$ \\
Party of judge 3 & $0.50^{* *}$ \\
Constant & $(0.146)$ \\
& $-3.15^{* *}$ \\
& $(0.179)$ \\
\hline
\end{tabular}

$\mathrm{n}=1,749 . \quad * *$ denotes significance at $\mathrm{p}=.01$.

Table 2: The Effect of Adding Democrats to a Panel in Unpublished Cases

\begin{tabular}{lll}
\hline Panel composition & $\begin{array}{l}\text { Probability of } \\
\text { pro-asylum decision }\end{array}$ & Standard error \\
\hline 3 Republicans, no Democrats & .041 & .0073 \\
2 Republicans, 1 Democrat & .124 & .0143 \\
1 Republican, 2 Democrats & .207 & .0222 \\
No Republicans, 3 Democrats & .301 & .0270 \\
\hline
\end{tabular}

2(a). Democratic and Republican panels are equally likely to publish whatever pro-asylum decisions they reach. The influence of ideology upon publication and voting is a subtle one that emerges only upon close analysis of the behavior of individual judges. With respect to the behavior of panels, the data provided no support for hypothesis 2(a): Democratic panels 
were no likelier than Republican panels either to publish pro-asylum decisions, or to leave anti-asylum decisions unpublished. As discussed above, an asylum seeker's odds of success were significantly higher before Democratic panels than before Republican panels, regardless of publication.

Those rare asylum seekers who secured favorable decisions from Republican panels, however, were just as likely to have their cases published as those who prevailed before Democratic panels: both types of panels published about $30 \%$ of their pro-asylum decisions. Nor did Democratic panels show any tendency, relative to Republican panels, to keep anti-asylum decisions unpublished. In fact, Democratic panels actually published a slightly greater fraction of their anti-asylum decisions than did Republican panels - just over 4\% for Democratic panels versus 3.5\% for Republican panels. Although contrary to hypothesis 2(a), these results are consistent with earlier findings by Songer, Smith, and Sheehan that Republican panels were more likely than Democratic panels to publish liberal decisions. ${ }^{115}$

The graphs below illustrate, for Democratic and Republican panels respectively, how asylum seekers fared and whether their cases were published. The difference in the likelihood of success on the merits is immediately apparent: overall, Democratic panels decided in favor of the asylum seeker $26 \%$ of the time, as opposed to just $10 \%$ for Republican panels. It is also obvious that Democratic panels published at nearly twice the overall rate of Republican panels. Within the category of wins for the asylum seeker, however, the proportion of decisions published was roughly the same for both Republican and Democratic panels. The same was true within the category of losses for the asylum seeker. Thus, Democratic panels published at a higher rate not because they published pro-asylum decisions at a higher rate than did Republican panels. Rather, Republican and Democratic panels were equally likely to publish their pro-asylum decisions; Democratic panels were simply much likelier to reach such decisions in the first place.

115. See supra text accompanying notes 63-66. 
Figure 6: How Democratic panels decided asylum cases

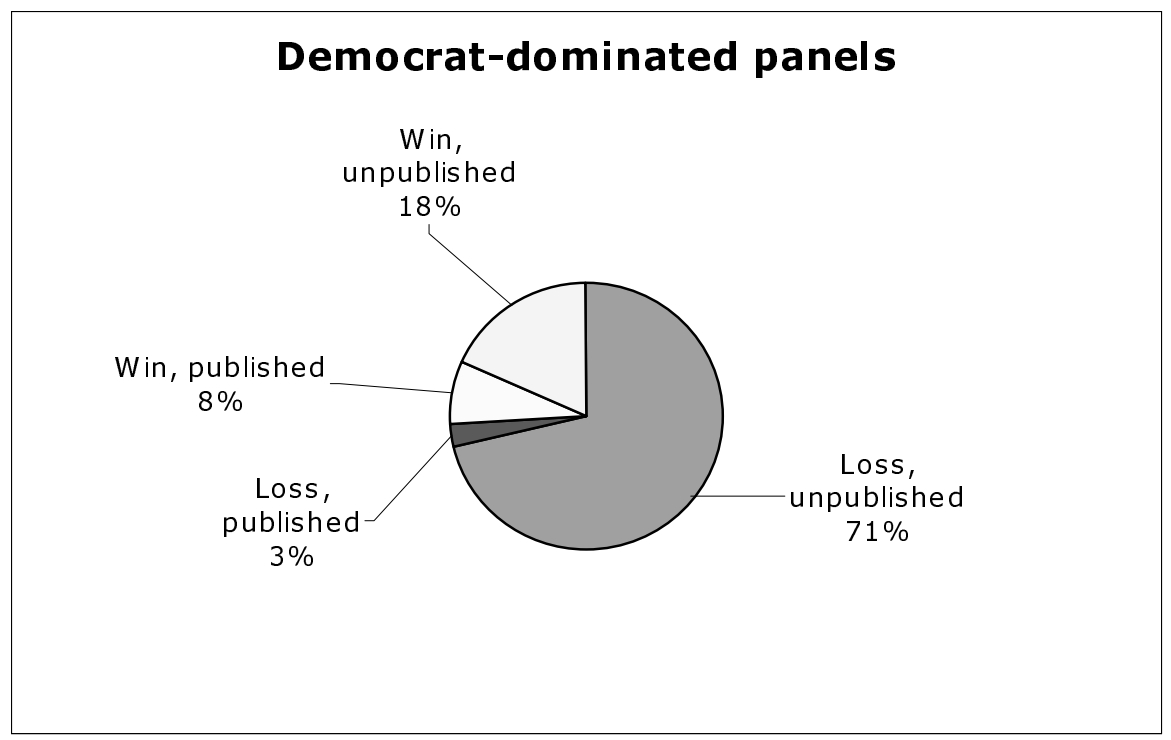


Law:

Figure 7: How Republican panels decided asylum cases

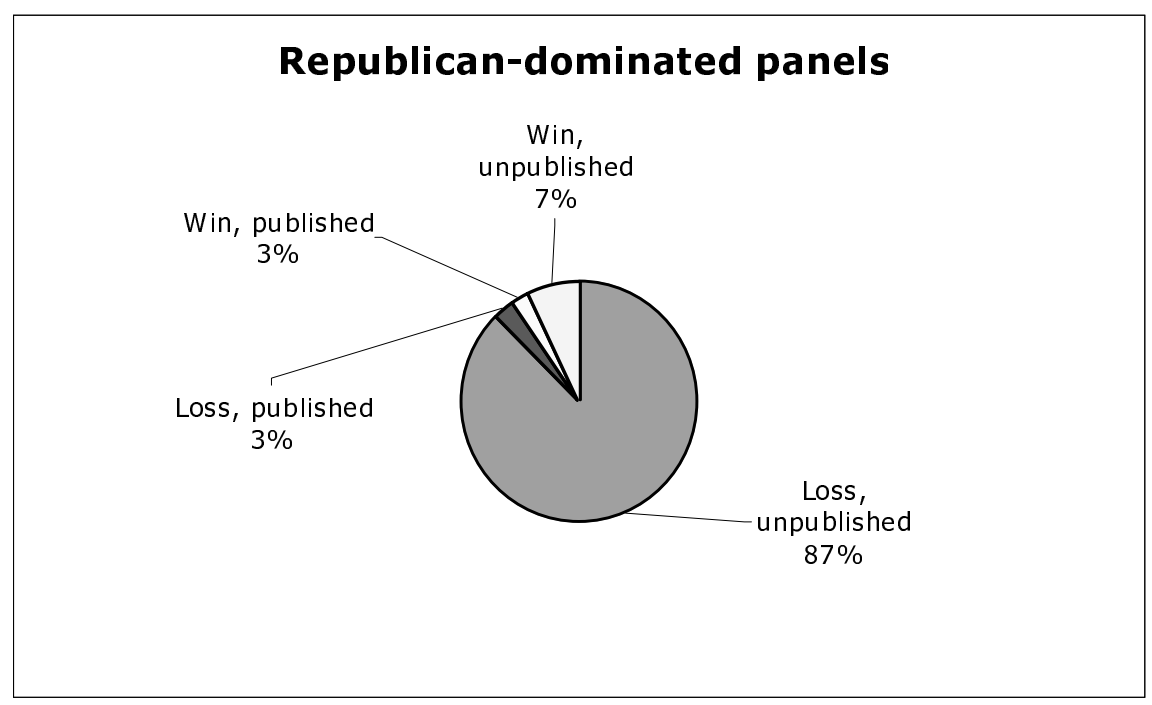

It is worth noting that 6 of the 26 pro-asylum decisions published by Republican panels stemmed from the involvement of one atypical judge, John T. Noonan, a law professor and Catholic intellectual appointed by President Reagan. ${ }^{116}$ Of the 40 senior and active Ninth Circuit judges who heard a meaningful number of asylum cases, Judge Noonan had the sixth most liberal voting record in asylum cases, a showing that placed him among a handful of liberal Carter appointees. ${ }^{117}$ Judge Noonan voted in favor of the asylum seeker nearly $30 \%$ of the time; by comparison, the other Republican members of the court did so in the aggregate just $10.5 \%$ of the time. Nevertheless, Judge Noonan was

116. In one of these six cases, the nominally Republican panel consisted of Judge Noonan, a district court judge from Hawaii sitting by designation, and a Carter appointee. The decision was ultimately reversed en banc by a vote of 9-2, with Judge Noonan dissenting. See Fisher v. INS, 79 F.3d 955, 967 (9th Gir. 1996) (en banc) (reversing Nasseri v. Moschorak, 34 F.3d 723 (9th Cir. 1994)). Three others were decided by a 2-1 vote, over the dissent of the other Republican appointee on the panel. See Perez-Lastor v. INS, 208 F.3d 773, 783-86 (9th Cir. 2000) (O'Scannlain, J., dissenting); Chanchavac v. INS, 207 F.3d 584, 593 (9th Gir. 2000) (O'Scannlain, J., dissenting); Escobar-Grijalva v. INS, 206 F.3d 1331, 1335 (9th Cir. 2000) (O'Scannlain, J., dissenting).

117. The only judges who cast a greater proportion of votes in favor of the asylum seeker were Judges Reinhardt (who voted in favor of the asylum seeker $61.7 \%$ of the time), Pregerson $(55.9 \%)$, Betty Fletcher $(50 \%)$, and Ferguson $(34.4 \%)$, all Carter appointees. Judge Boochever, another Carter appointee, edged out Judge Noonan by just $0.3 \%$. Judge Berzon, a Clinton appointee, voted in favor of the asylum seeker in 5 of the 15 cases she heard, a number too small to permit meaningful comparison. Visiting judges from other courts were excluded from the analysis. 
classified as a Republican - just as Judge Farris, a Carter appointee who voted against the asylum seeker over $96 \%$ of the time, was classified as a Democrat. The voting records of judges who heard a meaningful number of asylum cases are depicted in Figure 8.

Figure 8: How individual judges voted in asylum cases

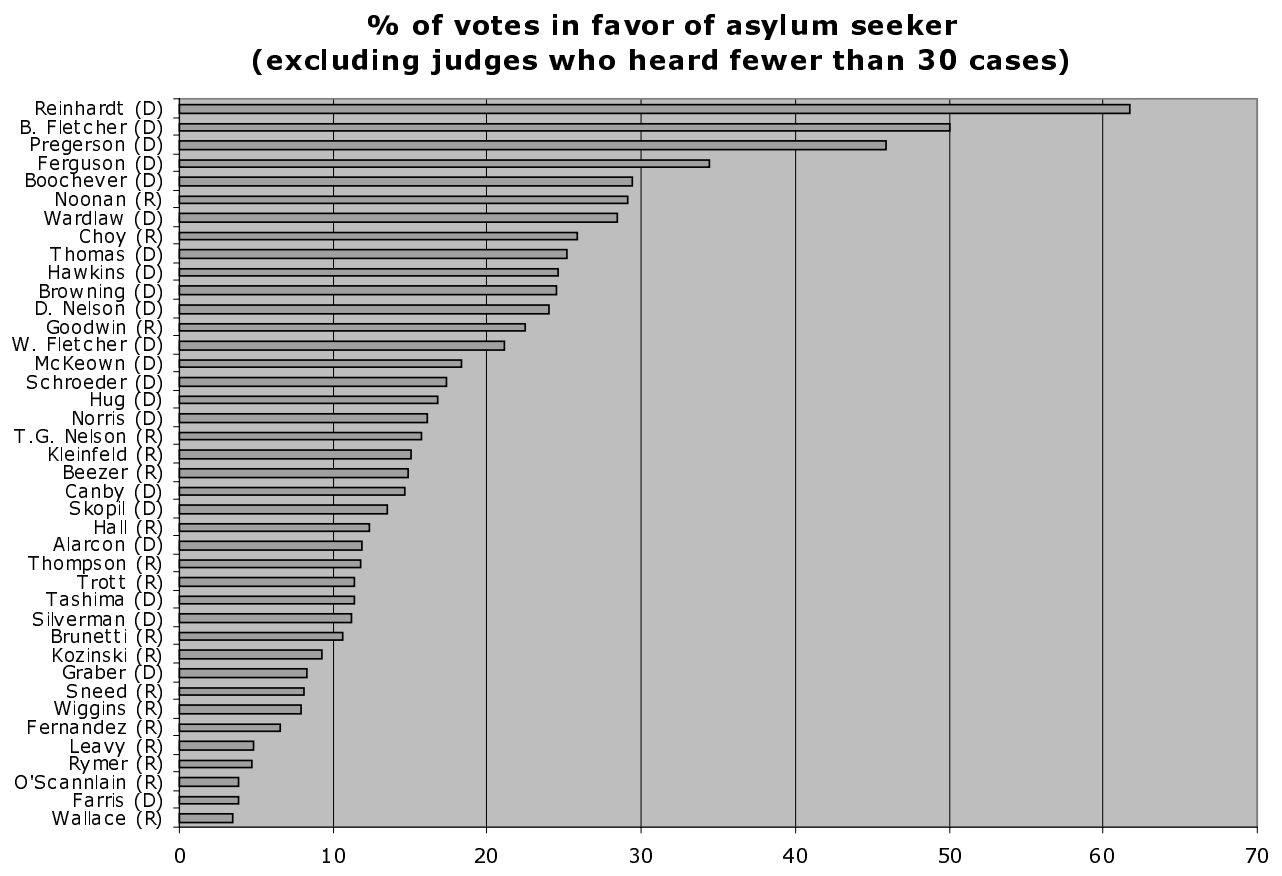

Judge Noonan notwithstanding, the publication patterns of neither Republican nor Democratic panels lend themselves to a strategic explanation. The infrequency with which anti-asylum decisions were published seems to reflect instead both the routine quality of decisions that affirm administrative denials of asylum, and the fact that routine decisions are by definition less likely to satisfy the criteria for publication. Most of the time, neither Republican nor Democratic panels found reason to reverse the agency's denial of asylum; even Democratic panels, it should be recalled, affirmed the Board of Immigration Appeals nearly three-quarters of the time. Cases in which there is no error correction for the court to perform would presumably tend, for that very reason, not to merit publication under the publication criteria. Conversely, cases in which the Board of Immigration Appeals is deemed to 
have erred would seem more likely to require a panel to "establish[], alter[], modif[y], or clarif[y] a rule of law," "call[] attention to a rule of law which appears to have been generally overlooked," or decide "a legal or factual issue of unique interest," thereby satisfying the criteria for publication. ${ }^{118}$

2(b). Some judges vote more ideologically in published cases than in unpublished cases. These findings regarding the publication patterns of Republican and Democratic panels are not, however, the end of the story. A different picture emerges upon testing of hypothesis $2(\mathrm{~b})$, concerning the effect of publication on the voting behavior of individual judges. The question of whether publication increased the propensity of Democratic appointees to vote in favor of the asylum seeker - or of Republican appointees to vote the other way - called for use of an item response model.

The conceptual framework underlying item response models is most easily explained in the context of educational testing. ${ }^{119}$ The goal of educational testing is to measure student ability. To that end, the items on a test must exhibit two characteristics. First, they must actually discriminate among students on the basis of ability: that is, the likelihood of a correct response must increase with the ability of the student. An item that discriminates perfectly is one that all students below a certain ability level have no chance of answering correctly, at the same time that all students above that level are guaranteed to answer correctly. An item that discriminates imperfectly is one that students above a certain ability level are somewhat more likely than students below that level to answer correctly. An item that does not discriminate at all is one that all students are equally likely to answer correctly. Second, test items must vary in difficulty. For example, if all items are pitched at a medium level of difficulty, the test may succeed at little more than separating the top half of the class from the bottom half. Easier items are required to distinguish amongst students in the bottom half, while harder items are needed to sort those within the top half.

In an item response model, the likelihood of a correct response is modeled as a function of three variables: (1) the ability of the student, (2) the extent to which the question discriminates on the basis of ability, and (3) the overall difficulty of the question. This model takes the following form:

118. 9TH CIR. R. 26-2

119. See generally Valen E. Johnson \& James H. Albert, Ordinal Data Modeling 182-87 (1999) (discussing item response models in the context of educational testing). 
Model 2: Estimating student ability

$$
\mu_{\mathrm{p}}=\beta_{\mathrm{j}(\mathrm{p}) 1} \mathrm{x}_{\mathrm{i}(\mathrm{p})}-\beta_{\mathrm{j}(\mathrm{p}) 2}
$$

where $\mathrm{i}$ indexes students, $\mathrm{j}$ indexes questions, and $\mathrm{p}$ indexes responses. Thus, $\mathrm{i}_{(\mathrm{p})}$ indicates which student gave response $\mathrm{p}$, while $\mathrm{j}_{(\mathrm{p})}$ indicates which question elicited response p. $x_{i}$ is the ability of student $i$, and $\mu_{p}$ is the natural logarithm of the odds ratio that response $\mathrm{p}$ is correct. ${ }^{120}$ $\beta_{\mathrm{j} 1}$, the "slope" of the equation, is the discrimination parameter for question $\mathrm{j}$. It measures the extent to which question $\mathrm{j}$ discriminates on the basis of ability. $\beta_{\mathrm{j} 2}$, the "intercept," controls the location of the item response curve; in substantive terms, it reflects the difficulty of question j. The model can be restated verbally: the probability of a correct response is determined by the interaction of the student's ability and the extent to which the question discriminates on the basis of ability, adjusted for the difficulty of the question.

The same model by which student ability is estimated can also be used to estimate a judge's propensity to vote in favor of asylum seekers. The likelihood of a vote in favor of the asylum seeker is modeled above as a function of three variables: (1) the propensity of the judge to vote in favor, (2) the extent to which the case at hand discriminates on the basis of this propensity, and (3) the extent to which the facts of the case favor the asylum seeker. In the equation above, we allow $\mathrm{i}$ to index judges instead of students, $\mathrm{j}$ to index cases instead of questions, and $\mathrm{p}$ to index votes instead of responses. Thus, $i_{(p)}$ indicates which judge cast vote $p$, while $j_{(p)}$ indicates which case supplied vote $p$. $x_{i}$ becomes the ideological disposition of judge $i$ toward asylum cases, while $\mu_{p}$ becomes the natural logarithm of the odds ratio that vote $\mathrm{p}$ is cast in favor of the asylum seeker. $\beta_{\mathrm{j} 1}$, the discrimination parameter, now measures the extent to which case $\mathrm{j}$ discriminates between judges on the basis of ideological disposition. Finally, $\beta_{\mathrm{j} 2}$ now reflects the extent to which the facts of case $\mathrm{j}$ inherently favor the asylum seeker. To restate this model verbally, the probability of a vote in favor of the asylum seeker is determined by the interaction of the judge's ideological disposition toward asylum cases and the extent to which the particular case discriminates on the basis of judicial ideology, adjusted for the extent to which the facts of the particular case favor the asylum seeker.

We are ultimately interested, however, not just in each judge's ideological disposition toward asylum cases, but in the effect of publication on how the judge votes. To that end, a new variable, 'publish,' is included to indicate whether case $\mathrm{j}$ was published. The coefficient on this new variable, $\delta_{i}$, is the factor by which judge $i$ responds to publi- 
cation: for instance, a positive value of $\delta_{i}$ means that when the case is published, judge $\mathrm{i}$ is more likely to vote for the asylum seeker. The augmented model takes the form:

\section{Model 3: Estimating judicial ideology and the effect of publication}

$$
\mu_{\mathrm{p}}=\beta_{\mathrm{j}(\mathrm{p}) 1} \mathrm{x}_{\mathrm{i}(\mathrm{p})}-\beta_{\mathrm{j}(\mathrm{p}) 2+} \delta_{\mathrm{i}(\mathrm{p})} \text { publish }_{(\mathrm{p})}
$$

This model requires the estimation of too many parameters, on the basis of too little useful data, to be run as a straightforward logistic or probit regression. The data set of nearly 1,900 cases is quickly exhausted in a variety of ways. For each of the 142 judges in the data set - a figure that includes senior and visiting judges - the model requires estimation of both the judge's ideal point, $\mathrm{x}_{\mathrm{i}}$, and the factor by which the judge responds to publication, $\delta_{\mathrm{i}}$.

Estimation of $\mathrm{x}_{\mathrm{i}}$ is made difficult by the rarity of dissent. Just as a unanimous vote on a particular legislative proposal gives us no opportunity to observe the ideological difference between Newt Gingrich and Barney Frank, unanimous panel decisions convey no information about the relative ideal points of the judges involved. Yet over $94 \%$ of the decisions in the data set were unanimous; out of 5,676 votes available for analysis, only 98 were dissents. Similarly, estimation of $\delta_{i}$ relies on a dearth of useful data: only $7.7 \%$ of the cases were published.

Finally, the cases themselves are a poor source of information about the case parameters, $\beta_{\mathrm{j} 1}$ and $\beta_{\mathrm{j} 2}$. The cryptic brevity of many unpublished asylum decisions made it impossible to code any useful information about the extent to which the facts favored the asylum seeker, much less the extent to which the case could be expected to elicit each judge's underlying ideological predisposition toward refugees. The most that could be gleaned with any consistency was the asylum seeker's country of origin, although even this fact sometimes went unstated. ${ }^{121}$ Moreover, even where this information was available, it did not prove valuable: neither country nor region of origin ${ }^{122}$ was significantly

121. Here is an example of an unpublished asylum decision, in its entirety:

Farah has failed to establish that he has a well-founded fear of persecution on account of political opinion. Political neutrality can constitute political opinion for purposes of asylum, but only if the petitioner demonstrates a causal connection between his political neutrality and fear of persecution. Even accepting Farah's testimony as true, the evidence indicates that Farah feared persecution not on account of an expression of neutrality, but because he had failed to provide information to the forces involved and had refused to join the fight. Because Farah cannot demonstrate his eligibility for asylum, he necessarily cannot prove that he is entitled to withholding of deportation.

Farah v. INS, No. 99-70321, 2000 WL 1809191 (9th Gir. Dec. 5, 2000) (mem.) (citations omitted).

122. All asylum cases were classified as originating in one of the following regions: (1) Africa, (2) 
correlated with an asylum seeker's chances of success on appeal. At the same time, even decisions that contain meaningful factual accounts may not constitute reliable sources of information about the asylum seeker's circumstances, as the factual accounts authored by judges are necessarily selective and may be tailored to justify the results reached.

Fortunately, Markov Chain-Monte Carlo methods (MCMG) make possible the estimation of models that might otherwise be intractable owing to missing data or the number of parameters to be estimated. ${ }^{123}$ Advances in computing power and software have brought these computationally intensive methods within the reach of social scientists. ${ }^{124}$ While an introduction to the mechanics of MCMC is beyond the scope of this paper, ${ }^{125}$ the basic idea is that the computer repeatedly explores possible values for the parameters using an algorithm that guarantees the search will visit "likely" parameter values more often than it will visit "unlikely" parameter values, where "likely" values are those better supported by the data. After many iterations, the parameter values visited by the algorithm can be treated as a random sample of parameter values best supported by the data: less likely parameter values appear less often in the algorithm's output than more likely parameter values. Estimates of the parameters are obtained by taking the average of the parameter values produced by the algorithm; similarly, the standard

Pacific \& East Asia, (3) South Asia, (4) Eurasia, (5) the Middle East, (6) Latin America \& Mexico, (7) Eastern Europe, (8) Western Europe (consisting of a single case from France), and (9) a final residual category for miscellaneous countries and cases in which the asylum seeker's country was not identified. Effort was made to approximate the regional classifications employed by the U.S. State Department, with exceptions. See U.S. Department of State, Countries and Regions, at http://www.state.gov/countries/ (last visited Apr. 16, 2004). The State Department currently groups Mexico and Latin America together as part of the "Western Hemisphere" region; it also does not distinguish between "Eastern Europe" and "Eurasia" but instead classifies them as part of a larger "Europe and Eurasia" region. For purposes of constructing a category that permitted a rough comparison of white and non-white asylum seekers, I sought to categorize "white" countries as belonging to Eastern Europe. Inevitably, some of these categorizations were to some extent arbitrary: Macedonia, for example, was coded as Eastern European, whereas Albania and Armenia were coded as Eurasian. The Pacific and East Asian region included Australia, Brunei, Burma, Cambodia, China (including Hong Kong and Macau), Fiji, Indonesia, Japan, Kiribati, Laos, Malaysia, Marshall Islands, Micronesia, Mongolia, Nauru, New Zealand, North Korea, Palau, Papua New Guinea, Philippines, Samoa, Singapore, Solomon Islands, South Korea, Taiwan, Thailand, Tonga, Tuvalu, Vanuatu, and Vietnam. The South Asia region consisted of Afghanistan, Bangladesh, Bhutan, India, Maldives, Nepal, Pakistan, and Sri Lanka. Eurasia comprised Albania, Armenia, Azerbaijan, Kazakhstan, Krygyzstan, Tajikstan, Turkmenistan, and Uzbekistan. Grouped into Eastern Europe were Albania, Belarus, Bulgaria, Estonia, Hungary, Macedonia, Romania, Russia, and the Ukraine. The Middle East included Algeria, Bahrain, Egypt, Iran, Iraq, Israel,Jordan, Kuwait, Lebanon, Libya, Morocco, Oman, Qatar, Saudi Arabia, Syria, Tunisia, the United Arab Emirates, and Yemen.

123. See Simon Jackman, Estimation and Inference via Bayesian Simulation: An Introduction to Markov Chain Monte Carlo, 44 AM.J. POL. SCI. 375, 377 (2000).

124. See id. at 400 .

125. For a helpful introduction to MCMC geared toward social scientists, see Jackman, cited above in note123; for a more technical discussion, see the opening chapters of JOHNSON \& ALBERT, cited above in note 119. 
deviation of a particular parameter is simply the standard deviation of the parameter values produced by the algorithm. ${ }^{126}$ In the present case, the model was run in WinBUGS ${ }^{127}$ for a burn-in period of 1,000 iterations, after which point 1,000 further samples were drawn for estimation purposes at intervals of 100 iterations.

Finally, any attempt to measure the relative ideological positions of judges requires the specification of a scale: to say that the temperature is twenty degrees, for example, means nothing until it is specified that 0 and 100 are the freezing and boiling points of water. In this case, I imposed a scale upon the ideal points of the judges by specifying that the $\mathrm{x}_{\mathrm{i}}$ values have a mean of 0 and a variance of 1 , such that they will vary mostly within a range of -2 to +2 . The computer algorithm then used the data to estimate $\mathrm{x}_{\mathrm{i}}$ for each of the judges, subject to this overall scaling constraint. Lower values of $\mathrm{x}_{\mathrm{i}}$ describe a more liberal attitude toward asylum seekers, while higher values describe a more conservative attitude.

Figure 9 depicts the estimated ideological positions of the judges with respect to asylum cases. Results are reported for active and senior Ninth Circuit judges who heard thirty or more asylum appeals, excluding en banc decisions. The actual estimate of $\mathrm{x}_{\mathrm{i}}$ for each judge is depicted by a dot. The lines that extend from each dot depict the 95\% confidence interval for that particular estimate: although no statistical estimate can ever be certain, it is $95 \%$ likely that the true value of $\mathrm{x}_{\mathrm{i}}$ lies within the range depicted. ${ }^{128}$ The fact that many confidence intervals overlap does not imply that the judges in question are statistically indistinguishable. For example, the probability that Judge Farris is in fact to the right of fellow Carter appointee Judge Schroeder is .982, or over $98 \%{ }^{129}$ Similarly, the probability that Judge Noonan is in fact to the left of fellow Reagan appointee Judge Kozinski is a whopping .999. Even judges whose estimates and confidence intervals differ only slightly, however, are unlikely to be in the wrong order. For example, although the estimates for Judges Tashima and Thompson are almost adjacent to one another, it is still $61.5 \%$ likely that Judge Tashima is in fact to the left of Judge Thompson.

126. For discussion of how simulation-based estimates can be used in lieu of estimates derived by traditional methods, see King et al., cited above in note 114, at 349-55.

127. WinBUGS is a software implementation of MCMC for Windows-based computers. It is available free of charge at http://www.mrc-bsu.cam.ac.uk/bugs/ (last visited May 16, 2004).

128. For discussion of how confidence intervals may be obtained from simulation-based methods of the kind used here, see King et al., cited above in note 114, at 355.

129. The probabilities reported here are simply the frequency, out of the 1,000 samples drawn from the simulation for estimation purposes, with which a given judge fell to the left (or right) of another judge. For an analogous use of simulation-based probability estimates, see again King et al, cited above in 114, at 355 . 
Figure 9: Estimates of the judges' attitudes toward asylum seekers

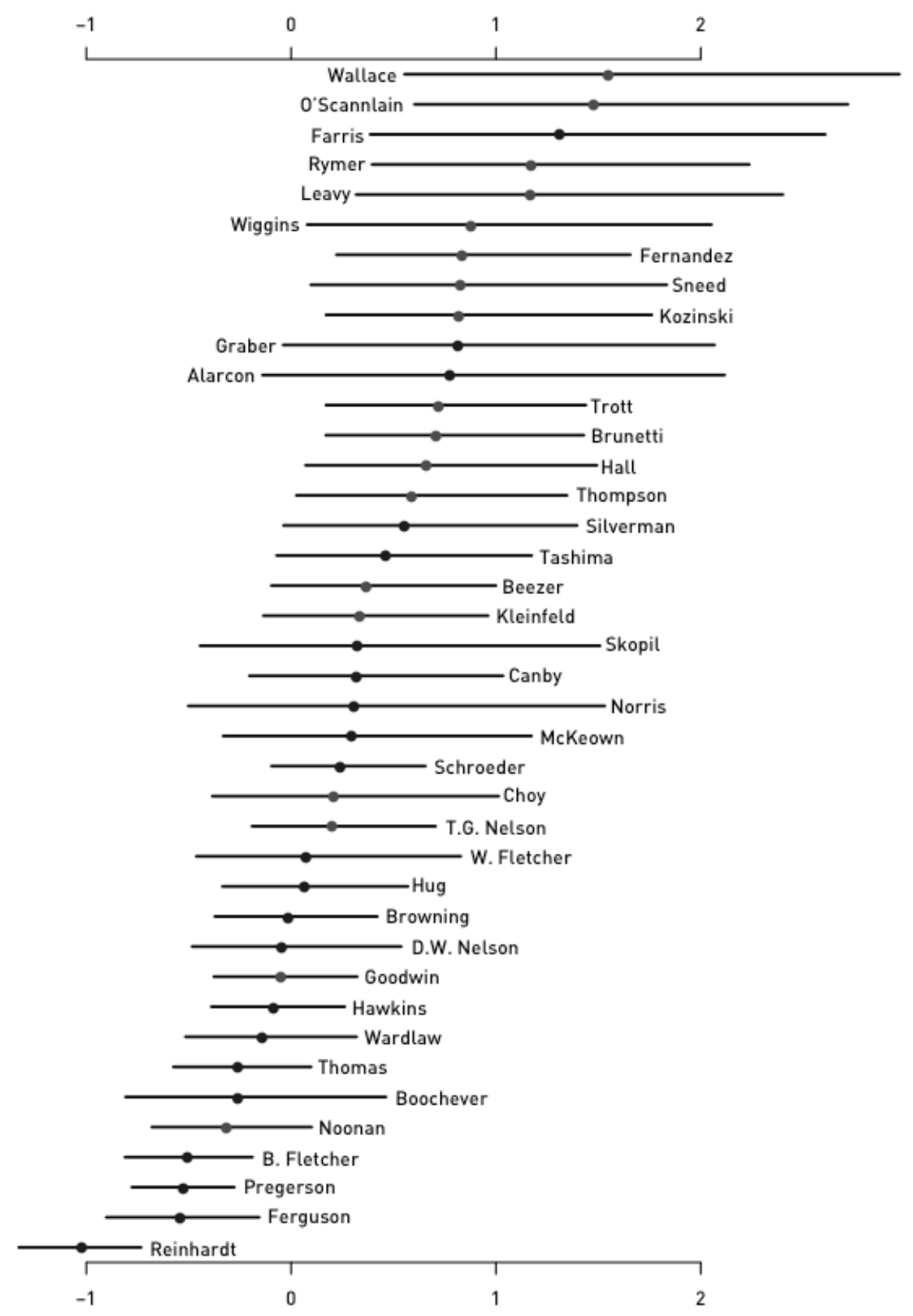

These estimates of $x_{i}$ provide a more accurate picture of where the judges lie with respect to one another than can be gleaned from the raw 
percentages of pro-asylum votes cast, as depicted in Figure 8. A simple comparison of voting percentages may reveal that two different judges both voted against asylum 9 out of 10 times, for example, but it will not give due weight to the fact that one of those judges happened to cast the only pro-asylum vote on an all-Democrat panel. By contrast, the computer algorithm used here seizes upon precisely such differences. As might be expected, the estimates of $\mathrm{x}_{\mathrm{i}}$ place the judges in an order similar, but not identical, to that observed in Figure 8. At the liberal end of the spectrum, for example, Judge Ferguson and Judge Betty Fletcher switch positions: the former is relatively more liberal, and the latter relatively less so, than is suggested by their raw voting records. Judge Noonan, meanwhile, remains by far the most pro-asylum of the Republican appointees and even overtakes Judge Boochever to become the fifth most pro-asylum judge overall. ${ }^{130}$ At the conservative end of the scale, Judge O'Scannlain now surpasses Judge Farris but still fails to take the pole position, as Judges Wallace and Reinhardt continue to reign supreme at the two extremes.

The estimated effect of publication upon the voting behavior of each judge is reported below in Table 3. Again, results are reported only for active and senior Ninth Circuit judges who heard thirty or more asylum cases, and en banc decisions were excluded from the analysis. A positive value for $\partial$ indicates that publication made the judge in question more likely to vote in favor of the asylum seeker, while a negative value indicates the opposite. The number of votes cast by each judge in published asylum cases is given in parentheses. For many judges, a sheer lack of data doomed any estimate of $\partial$ to insignificance: the extreme cases are Judges McKeown and Skopil, who participated in no published asylum decisions at all. Indeed, notwithstanding the scope of the data set, which spans the votes of 142 judges in 1,892 cases over 10 years, there were only sixteen judges who voted in ten or more published asylum cases. For the majority of these judges - including the extremes, Reinhardt and Wallace, both of whom were well represented in the data-there is little reason to think that the decision to publish had any effect on how they voted. However, a quarter of this groupJudges Betty Fletcher, Hawkins, Pregerson, and Thomas, all Democratic appointees - proved more likely to favor the asylum seeker in published cases than in unpublished cases.

130. Again, Judge Berzon is excluded from the comparison. See supra note 117. 
Table 3: The Extent to Which Publication Affected Individual Voting

\begin{tabular}{|c|c|c|}
\hline $\begin{array}{l}\text { Fudge } \\
\text { (\# of published votes) }\end{array}$ & Estimate of $\partial$ & $95 \%$ confidence interval \\
\hline Alarcon (4) & 0.26 & $(-1.52,2.01)$ \\
\hline Beezer (8) & 0.75 & $(-0.86,2.38)$ \\
\hline Boochever (6) & 0.66 & $(-1.03,2.39)$ \\
\hline Browning (7) & 0.87 & $(-0.73,2.58)$ \\
\hline Brunetti (11) & 0.49 & $(-1.26,2.20)$ \\
\hline Canby (2) & 0.23 & $(-1.63,2.10)$ \\
\hline Choy (4) & 0.49 & $(-1.24,2.24)$ \\
\hline Farris (4) & 0.61 & $(-1.26,2.51)$ \\
\hline Ferguson (8) & 1.43 & $(-0.16,3.08)$ \\
\hline Fernandez (8) & -0.06 & $(-1.67,1.53)$ \\
\hline B. Fletcher (20) & $1.48 *$ & $(0.11,2.90)$ \\
\hline W. Fletcher (1) & 0.19 & $(-1.67,2.05)$ \\
\hline Goodwin (10) & 0.68 & $(-0.95,2.29)$ \\
\hline Graber (3) & -0.12 & $(-2.03,1.76)$ \\
\hline Hall (11) & 0.62 & $(-0.97,2.26)$ \\
\hline Hawkins (24) & $2.28 *$ & $(0.98,3.68)$ \\
\hline Hug (5) & 0.56 & $(-1.18,2.29)$ \\
\hline Kleinfeld (11) & 1.09 & $(-0.43,2.66)$ \\
\hline Kozinski (6) & 0.69 & $(-1.07,2.48)$ \\
\hline Leavy (2) & -0.01 & $(-1.97,1.93)$ \\
\hline McKeown $(0)$ & 0.00 & $(-1.97,1.94)$ \\
\hline D.W. Nelson (9) & 0.82 & $(-0.77,2.47)$ \\
\hline T.G. Nelson (12) & 1.26 & $(-0.26,2.81)$ \\
\hline Noonan $(7)$ & 1.61 & $(-0.03,3.22)$ \\
\hline Norris (1) & 0.21 & $(-1.64,2.15)$ \\
\hline O'Scannlain (16) & 0.46 & $(-1.18,2.10)$ \\
\hline Pregerson (40) & $2.27 *$ & $(1.10,3.45)$ \\
\hline Reinhardt (21) & 1.10 & $(-0.25,2.49)$ \\
\hline Rymer (6) & 0.00 & $(-1.79,1.85)$ \\
\hline Schroeder (11) & 1.12 & $(-0.38,2.70)$ \\
\hline Silverman (4) & 0.84 & $(-0.86,2.60)$ \\
\hline Skopil (0) & 0.00 & $(-2.01,1.95)$ \\
\hline Sneed (1) & -0.06 & $(-1.97,1.92)$ \\
\hline Tashima (12) & 0.93 & $(-0.63,2.55)$ \\
\hline Thomas (12) & $1.73 *$ & $(0.30,3.21)$ \\
\hline Thompson (10) & 1.19 & $(-0.39,2.80)$ \\
\hline $\operatorname{Trott}(16)$ & 1.08 & $(-0.38,2.56)$ \\
\hline Wallace (14) & -0.03 & $(-1.76,1.77)$ \\
\hline Wardlaw (8) & 1.29 & $(-0.30,2.91)$ \\
\hline Wiggins $(9)$ & 0.03 & $(-1.78,1.80)$ \\
\hline
\end{tabular}

* denotes significance at $p=.05$. 
These results indicate, consistent with hypothesis 2(a), that some judges have a noticeable tendency to make "good law," and to avoid making "bad law," by casting "good" (ideologically preferred) votes in published cases, while restricting "bad" (ideologically disfavored) votes to unpublished cases. Such behavior is hardly epidemic: most judges, including some unmistakably possessed of ideological leanings, demonstrated no significant tendency to vote strategically in light of publication. Unless such strategic behavior is widespread among judges, however, it is unlikely to be detected by a simple comparison of the aggregate publication records of majority-Democratic and majority-Republican panels. This fact alone explains the failure of past studies to find evidence of strategic judicial lawmaking. Here, the effect of publication upon voting was observed only upon estimation of a computationally intensive model focused upon the behavior of individual judges.

2(c). Homogenous panels are not more likely than divided panels to publish. Finally, tests of hypothesis 2(c) yield no significant evidence that panel homogeneity affects publication. It was hypothesized that undivided panels would publish at a more aggressive rate than divided panels, in the absence of a minority judge to brake the lawmaking inclinations of the majority. An initial comparison of publication rates suggests a significant and unexpected relationship between panel composition and publication: the more Democrats on the panel, the greater the publication rate. Divided panels decided 1,399 cases, of which they published 103, or $7.4 \%$. By comparison, all-Democrat panels published 27 of their 214 decisions, or $12.6 \%$, while all-Republican panels published 13 of their 279 decisions, or just $4.7 \%$. A two-sample test of proportions confirms that all-Democrat panels published at a significantly higher rate than divided panels $(\mathrm{p}<.01)$. The difference between all-Republican and divided panels also approached statistical significance $(\mathrm{p}=.104)$.

These results are open, however, to an alternative interpretation. As reported above, Democratic panels are much likelier to reach proasylum decisions than Republican panels. Moreover, both types of panels are more likely to publish pro-asylum decisions than anti-asylum decisions. It is therefore possible that all-Democrat panels publish at a higher rate than other panels not because they consist entirely of Democrats, but rather because Democrats tend to render pro-asylum decisions, and such decisions are inherently more worthy of publication in the eyes of Democratic and Republican appointees alike. One way to test this possibility is to run a logistic regression in which both the outcome of the decision and the number of Democrats on the panel are used to predict whether the decision will be published. The use of both outcome and panel composition to predict publication enables us to observe the effect of panel composition independent of the effect of outcome. 
Model 4: Using panel composition to predict publication

$\operatorname{Pr}($ publication $)=\alpha+\beta_{\cap}($ outcome $)+\beta_{2}($ number of Democrats $)$

This regression analysis confirms the alternative interpretation: once we control for the outcome of the decision, the number of Democrats on the panel ceases to have any significant effect on the likelihood of publication $(p=.6)$. This result is unsurprising, insofar as it is consistent with Merritt and Brudney's finding that panel composition was not a significant predictor of publication in the area of labor law. ${ }^{131}$

3. Changes in the likelihood of reversal may affect publication behavior. Hypothesis 3(a) concerned the possibility that panels modify their voting and publication behavior in response to changes in the likelihood of en banc reversal. In particular, it was hypothesized that the shift from Republican to Democratic control of the Ninth Circuit in the late 1990s may have encouraged Democratic panels to publish pro-asylum decisions more aggressively, while discouraging Republican panels from publishing anti-asylum decisions. The data provide some support for this hypothesis, but only with respect to Democratic panels.

Table 4 compares publication rates for decisions reached from 1992 through 1997, a period during which Republicans held the majority of the court's active judgeships, with those reached from 1999 through 2001, a period of solidly Democratic control. The raw numbers suggest an across-the-board increase in publication rates - for both Democratic and Republican panels, regardless of outcome - between the two time periods. Only one of these increases, however, approached statistical significance ${ }^{132}$ - namely, the increase in the rate at which Democratic panels published decisions that favored the asylum seeker. By contrast, although considerable in percentage terms, the increase in the rate at which Republican panels published pro-asylum decisions was not statistically significant, given the smaller numbers of cases involved.

131. See supra note 60 and accompanying text.

132. $\mathrm{P}=.08$, per a two-sample test of proportions. 
Table 4: Publication Rates, 1992-97 Versus 1999-2001

\begin{tabular}{|c|c|c|c|c|c|}
\hline & & \multicolumn{2}{|c|}{ DEMOCRATIC PANELS } & \multicolumn{2}{|c|}{ REPUBLICAN PANELS } \\
\hline & & $\begin{array}{l}\text { 1992-97: } \\
\text { Republican } \\
\text { control }\end{array}$ & $\begin{array}{l}\text { 1999-2001: } \\
\text { Democratic } \\
\text { control }\end{array}$ & $\begin{array}{l}\text { 1992-97: } \\
\text { Republican } \\
\text { control }\end{array}$ & $\begin{array}{c}\text { 1999-2001: } \\
\text { Democratic } \\
\text { control }\end{array}$ \\
\hline \multirow[t]{2}{*}{$\begin{array}{l}\text { PUBLICATION } \\
\text { RATE: }\end{array}$} & $\begin{array}{l}\text { Pro-asylum } \\
\text { decisions }\end{array}$ & $\begin{array}{l}14 \text { out of } \\
69(20.3 \%)\end{array}$ & $\begin{array}{l}46 \text { out of } \\
145(31.7 \%)\end{array}$ & $\begin{array}{l}16 \text { out of } \\
70(22.9 \%)\end{array}$ & $\begin{array}{l}8 \text { out of } 22 \\
(36.4 \%)\end{array}$ \\
\hline & $\begin{array}{l}\text { Anti- } \\
\text { asylum } \\
\text { decisions }\end{array}$ & $\begin{array}{l}8 \text { out of } \\
237(3.4 \%)\end{array}$ & $\begin{array}{l}15 \text { out of } \\
355(4.2 \%)\end{array}$ & $\begin{array}{l}15 \text { out of } \\
554(2.7 \%)\end{array}$ & $\begin{array}{l}9 \text { out of } \\
221(4.1 \%)\end{array}$ \\
\hline
\end{tabular}

These results raise a problem of inference: can one be certain that Democratic panels published a greater proportion of their pro-asylum decisions because they perceived a lower risk of en banc reversal, or might there be some other explanation for the increase? One alternative explanation, at least, seems unlikely: there do not appear to have been any changes in asylum law between 1992 and 2001 that called for more frequent publication of pro-asylum decisions. ${ }^{133}$ Nor does it appear that the judges added to the court after 1998 were uniquely intent upon publishing pro-asylum decisions. Although Clinton's appointment of eleven judges to the Ninth Circuit in his second term certainly enhanced an asylum seeker's chances of drawing a sympathetic panel and prevailing on the merits, those new judges did not contribute disproportionately to the body of pro-asylum decisions published after their arrival. ${ }^{134}$ In the absence of a strong competing explanation, the hypothesis that the decision to publish is influenced by the likelihood of en banc reversal enjoys some empirical support and merits further investigation.

The unexpected increase in the rate at which Republican panels published pro-asylum opinions raises questions as well. Although this increase was not statistically significant $(p=.21)$, the data were admittedly scarce; more data along the same lines might be difficult to dismiss. In the alternative, even if the increase signifies nothing of substance, one is left nevertheless with yet another asymmetric finding that Democrats, but not Republicans, approach voting and publication strategically to some extent. This asymmetry is itself unexpected and calls for explanation.

133. See supra notes $84-86$ and accompanying text.

134. By the end of the 1999-2001 period, Clinton's second-term appointees constituted 11 of the court's 18 active Democrats but participated in only 12 of the 46 pro-asylum decisions published during that same period. Judge Wardlaw alone was responsible for 8 of those 12 cases; she, in turn, did not exhibit a significant tendency to favor asylum seekers in published cases. See supra tbl.3. 


\section{GONCLUSION}

This Article has presented empirical evidence of two forms of strategic behavior on the Ninth Circuit, neither of which has been documented in previous studies of the courts of appeals. First, some judges appear to take into account whether a decision will be published when deciding how to vote. When faced with publication of the resulting decision, a handful of Democratic appointees demonstrated a heightened tendency to vote in favor of the asylum seeker. This finding is difficult, if not impossible, to explain on anything other than strategic grounds. It strongly suggests that, to some extent, judges vote strategically and bargain amongst themselves so as to maximize the amount of "good law" and minimize the amount of "bad law" that will appear in the pages of the Federal Reporter and bind their colleagues in subsequent cases.

Second, the evidence suggests that a decrease in the likelihood of en banc reversal may have emboldened Democratic panels to publish a greater proportion of their pro-asylum decisions. No comparable patterns were observed, however, among Republican panels or judges: although Republican panels were much less likely than Democratic panels to rule in favor of the asylum seeker in the first place, they showed no reluctance to publish the rare pro-asylum decisions that they did reach. This unexpected asymmetry between Republican and Democratic judicial behavior invites further investigation, as does the effect of the threat of reversal on the decision to publish.

Their intrinsic importance aside, these findings have methodological implications for future research on judicial behavior. First, they demonstrate the inherent limitations of aggregate-level analysis. Significant patterns in judicial behavior can go undetected if researchers consider only how groups of judges act, to the exclusion of how individual judges behave. For example, as noted above, earlier work by Merritt and Brudney found no evidence that the number of Democrats on a panel influences a panel's tendency to publish pro-union decisions. ${ }^{135}$ Similarly, in the present case, it was found that Democratic panels were no more likely than Republican panels to publish pro-asylum decisions. ${ }^{136}$ Examination of panel-level behavior failed, however, to detect the fact that some individual judges do take publication into account when deciding how to vote on the merits. It may be easy to divide judges into groups and calculate percentages of interest, but such crude statistical

135. See supra text accompanying notes 57-59 (discussing Merritt \& Brudney's finding that "[p]anels with more Democrats showed no tendency to publish pro-union results").

136. See supra Part VI.2(a)-(b) (discussing disparate findings with respect to hypothesis 2(a), on the voting and publication behavior of panels, and hypothesis $2(\mathrm{~b})$, on the behavior of individual judges). 
methods are capable of discerning only relatively widespread phenomena. Case-by-case, judge-by-judge analysis is inherently more discerning but also increases the number of variables to be estimated to an extent that may defy conventional regression techniques. Fortunately, as demonstrated here, advanced statistical methods that can often overcome such difficulties are increasingly within the reach of social scientists and legal academics alike. ${ }^{137}$

Second, the findings presented here deal yet another blow ${ }^{138}$ to the notion that unpublished cases may be disregarded for research purposes. Even in an era of increasingly easy electronic and print access to unpublished decisions, it remains common for studies of judicial behavior to rely exclusively upon published opinions for data, even when the particular courts and time periods in question are characterized by limited publication practices. ${ }^{139}$

It is especially unfortunate that the advent of an extensive, publicly funded database of published appeals court decisions appears to be having the unintended consequence of promoting continued reliance

137. See supra notes 123-127 and accompanying text (discussing Markhov Chain-Monte Carlo methods and the WinBUGS software package).

138. See, e.g., Merritt \& Brudney, supra note 8, at 115 \& n.135; Peter Siegelman \& John J. Donohue III, Studying the Iceberg from Its Tïp: A Comparison of Published and Unpublished Employment Discrimination Cases, 24 LAW \& SOC'Y REV. 1 133, 1145 n.30, 1165-66 (1990) (citing Sir Arthur Eddington for the proposition that "if you catch fish with a net having a 6-inch mesh, you are liable to formulate the hypothesis that all fish are more than 6 inches in length"); Wasby, supra note 38, at 330 (comparing exclusive reliance upon published opinions to a "drunkard's search," in which "the drunk looks for money not where it is dropped, but under the street light"); Ruth Colker, The Americans with Disabilities Act: A Windfall for Defendants, 39 HARV. C.R.-C.L. L. REV. 99, 104-05 (1999) (arguing that failure to account for unpublished decisions results in a highly misleading picture of how plaintiffs fare under the Americans with Disabilities Act); Songer, supra note 23, at 313 (concluding that "many interesting and theoretically important studies cannot be validly undertaken" if unpublished decisions are wholly excluded from analysis). Even Songer, however, has not consistently followed his own advice. See, e.g., Donald R. SONGER ET AL., ContinutTy AND Change ON THE UNTTED STATES COURTS OF APPEALS xix-xx, 20, 54-101 (2000) (using an extensive database of published opinions to chart changes in the types of litigation brought before the circuit courts); $i d$. at 119-30 (relying upon the same database to assess the effects of party and region on judicial voting); Donald R. Songer \& Susan Haire, Integrating Alternative Approaches to the Suddy of fudicial Voting: Obscenity Cases in the U.S. Courts of Appeals, 36 AM.J. POL. SCI. 963, 969 (1992) (relying upon published opinions to assess the predictive power of judicial ideology and other variables upon appellate decisionmaking).

139. See, e.g., Cross, supra note 95, at 1498-1514 (relying upon a database of published circuit court opinions to examine the effects of judicial ideology and other variables upon appellate decisionmaking); Joseph L. Smith \& Emerson H. Tiller, The Strategy of fudging: Evidence from Admimistrative Law, 31 J. LEGAL STUD. 61, 69 (2002) (relying upon published circuit court opinions to study strategic use of legal doctrines in administrative law); supra note 138 (citing studies by Songer and various co-authors). To be sure, not all studies fall into the same trap. See, e.g., Richard L. Revesz, Congressional Influence on fudicial Behavior?' An Empirical Examination of Challenges to Agency Action in the D.C. Circuit, 76 N.Y.U. L. REV. 1100, 1122 (2001) (examining all D.C. Circuit decisions over a period of decades for evidence of congressional influence on judicial behavior); Revesz, supra note 44, at 1720 \& n.15 (describing use of electronic sources to obtain unreported decisions for analysis). 
among researchers upon published opinions. ${ }^{140}$ Because empirical research is an exhausting enterprise, researchers find it more attractive to use existing data sets than to create their own. In the present case, however, an examination of only published asylum decisions would have led to at least two grossly erroneous conclusions - namely, that Republican panels were just as likely as Democratic panels to rule in favor of asylum seekers; and that Republican panels did not hear nearly as many asylum cases as Democratic panels.

Although it remains an open question whether similar facts would hold true of other courts and areas of law, researchers would be well advised either to incorporate a sample of unpublished decisions, or to justify their reliance on published opinions in light of the research questions posed. Because judicial ideology interacts to some degree with the selection of cases for publication, it is particularly inappropriate to draw conclusions about the effect of ideology on judicial decisionmaking from analysis of published opinions alone. Simply to assume that judges can and do apply inherently vague publication criteria to precisely their intended effect, in a consistent manner untainted by considerations of ideology or strategy, is wishful thinking.

140. As Wasby observes, "most of the growing number of political scientists' studies of the United States Circuit Courts of Appeals are based only on the sample of published opinions available in the new Court of Appeals Database." Wasby, supra note 38, at 330; see Donald R. Songer, United States Courts of Appeals Database Phase 1, 1925-1988, available at http://www.icpsr.umich.edu:8080/ICPSR-STUDY/ 02086.xml (May 27, 1998); SONGER ET AL., supra note 138, at xix-xx, 20-22, 145-52 (describing the database). 